\title{
Kelâm Atomculuğunun Tümel Modeli: Cüveynî Örneğinde Hâller Teorisi*
}

\author{
Mehmet Aktaş**
}

\begin{abstract}
Özet
İmâmü'l-Haremeyn Ebü'l-Meâlî el-Cüveynî (ö. 478/1085) ve öncesi Eş'arî kelâm sisteminde yer alan hâller teorisi, bu sistemin tümeller anlayışı şeklinde değerlendirilebileceği gibi ortak hakikatler şeklinde de değerlendirilebilir. Ancak bu dönemde söz konusu teoriyi savunanlar ve savunmayanlar olmak üzere iki farklı hakikat anlayışı göze çarpar. Hâlleri reddedenler hakikatleri nominal çerçevede değerlendirirken, bu teoriyi savunanlar ise realist bir tavirla mevcutlar için ortak hâl ve hakikatten bahseder. Bu doğrultuda onlar her ne kadar hâller teorisi üzerinden realist bir yöntem takınarak Aristotelesçi tümel anlayışına yaklaşmış olsalar da aralarında temel farklar bulunur. Aristotelesçi tümel anlayışı nesnelere dair olmasına karşın kelâmcıların hâlleri, hâdis âlemde nesnelerin bütününe değil, onların yapıtaşları olan cevher-araz ikilisinin kapsamıla sınırlıdır. Yani Cüveynî özelinde kelâmcılar nesnelerin yapıtaşlarında realist ancak nesneler bütünü dikkate alındığında nominalisttirler. Ayrıca hâller, Aristotelesçi tümellerden farklı olarak önermelerde asla konu kabul edilmemektedir. Hâllerde gözlemlenen bu durum nedeniyle söz konusu dönemin Eş‘arî kelâmında ikinci cevherler yer bulamamıştır. Son olarak da arazlar ve ilâhî mânâlar sıfat kategorisinden çıkartılıp yerine hâller yerleştirilmiştir. Böylece hakikî anlamda cevherler ve Zât-i ilâhînin yanında arazlar ve ilâhî mânâlar da zât kategorisine dâhil edilmiştir. Dolayısıyla zât-sıfat bağlamında yeni bir kelâm dili ortaya çıkmış ve hâllere ontik bir "yer" biçilmiştir. Ancak bu yer; kelime, zihin, nesne veya nesnenin ötesi değildir. Bu çerçeveyle hâller teorisi "şekil", "kapsam" ve "yer" olmak üzere bu makalede üç noktada değerlendirilmeye tabi tutulacaktır.
\end{abstract}

Anahtar sözcükler: Cüveynî, hakikat, hâller (ahvâl), tümeller, ikinci cevherler, realizm, nominalizm

\begin{abstract}
The theory of ahwāl, which can be evaluated as the understanding of universals of Imām al-Haremeyn Ebü'l-Maālī al-Juwaynī (d. 478/1085) and its earlier Ash'arī theological system, is also considered as the common truths of this system. However, in this period, two different conceptions of truth stand out: those who adopt the theory of ahwāl and those who do not. While those who reject ahwāl evaluate the truths in a nominal framework, those who defend this theory talk about the common state and truth for the existing (mevcūd) in a realistic manner. In this direction, although they have approached the Aristotelian understanding of universal by capturing a realist method through the theory of states, there are fundamental differences between them. Although the Aristotelian understanding of the universal is about the objects, the ahwāl of the Theologians are limited to the essence-accident binary, which are the building blocks of objects in the created (hädis) universe. In other words the Theologians are realists in the building blocks of objects, but nominalists in the object's layer. In addition, ahwāl are not accepted as subject in propositions, unlike Aristotelian universals. Because of this form of the ahwāl, the second essences were not included in the Ash'ari theology of the period. Finally, ahwāl are accepted as adjectives beyond the figurative narrative. For this reason, although the "place" of states is still uncertain, this place is not the word, mind, object or beyond-object. In this framework, the theory of states will be evaluated in three ways in this article, namely "figure", "extend" and "place".
\end{abstract}

Keywords: Cüveynī, truth, ahwāl (states), universals, realist, nominalist.

* Bu çalışma 2020 yılında Marmara Üniversitesi Sosyal Bilimler Enstitüsü bünyesinde tamamladığımız “Cüveynî̀de Tanım Teorisi” başlıklı doktora tezi esas alınarak hazırlanmıştır.

** Dr., Hakkari Üniversitesi, İlahiyat Fakültesi, Kelâm Anabilim Dalı. İletişim: aktashmehmet@gmail.com. 


\section{Giriş}

Mütekaddimîn kelâmcılar tarafından çokluk için "ortak sıfatlar" şeklinde tasarlanan hâllerin klasik felsefedeki tümeller anlayışılla bağdaşan tarafları bulunur. Sözcüklerin temsil ettiği bu sıfatların soyut referanslı olması, sözcükten ibaret kabul edilmemesi, yüklendiği konudan başka olması (zâid) ve en önemlisi de ortak sıfatlar şeklinde tasarlanması söz konusu bağdaşmanın göze çarpan yönleridir. Temelleri Muammer'in (ö. 215/830) mana teorisine dayanan ve mana teorisinin içerdiği teselsül paradoksunun aşılması amacıyla ilk defa Ebû Hâşim (ö. 321/933) tarafından "hâller/ ahvâl" adı altında şekillenen bu teori, ${ }^{1}$ birtakım önermelerin yüklemleriyle sınırlıdır. "Allah âlimdir" gibi bir önermede yer alan yüklemin, önermenin konusundan ibaret kabul edilmesi, Ebû Hâşim tarafından anlamsız bir önerme yapısı (totoloji) şeklinde değerlendirilmiştir. Dolaysıyla ona göre yüklemi simgeleyen "âlim" terimi, önermenin konusu olan Allah'tan "başka" (zâid) olmalıdır. Önermedeki yüklemi özneden ayrı değerlendiren Ebû Hâşim, bu yolla kelâm ilminin en önemli konusu olan sıfatlar problemini çözmeye çalışmıştır. Temel kaygısı ve çözüm önerisi bu minvalde olan Ebû Hâşim, ahvâl teorisini mensup olduğu Mu'tezile mezhebinin dinamikleriyle uyumlu şekilde tasarlamıştır. Eş'arîlerden Bâkıllânî (ö. 403/1013) ve Cüveynî de (ö. 478/1085) bu teoriyi Eş'arî mezhebine uyarlamaya çalışarak kullanmışlardır.

Cüveynînin öğrencilerinden Gazzâlî (ö. 505/1111) ve onun Kitâbu'l-İrşâd ilâ kavâtt' 'i'l-edille fî usûli'l-i'tikâd eserine şerh yazanlar başta olmak üzere birçok müteahhirîn kelâmcı, hâllerin tümeller (külliyyât) olduğu hususunda neredeyse hemfikirdirler. Bu iddiadan hareketle -kelâm atomculuğunu da (cevher-araz teorisi) göz önünde bulundurarak- hâllerin klasik felsefedeki tümel modelleriyle mukayesesi, bu makalenin temel amacını oluşturmaktadır. Bu amaç doğrultusunda hâller -Bâkıllânî ve Cüveynînnin görüşleri merkeze alınarak- üç noktada incelenecektir. Bunlar, hâllerin sırasıyla, "şekil", "kapsam" ve "yer" bakımından incelenmesi şeklinde olacaktır. Birincisinde hâllere atfedilen temel aksiyomlar analiz edilecektir. İkincisinde tikel varlıklara yüklem olan hâllerin hâdis varlıklardan sadece cisimlerin yapıtaşı olan cevherler ve arazlarla sınırlı olduğu düşüncesi temellendirilmeye çalışılacaktır. Üçüncüsünde ise bu kuramın kavramcilık da dâhil olmak üzere tam anlamıyla herhangi bir realist kuramla bağdaşmadığına dikkat çekilecektir. Dolayısıyla hâller kuramının kelâm atomculuğuna uyarlanan ve özgün yönleri bulunan bir tümel modeli olduğu bu makalenin temel iddiası olarak öne çıkacaktır.

1 Harry Austryn Wolfson, The Philosophy of the Kalam (Cambridge: Harvard University Press, 1976), 167-68; Mehmet Dağ, “İmam el-Haremeyn el-Cüveyni'de Nedensellik Kuramı”, Ondokuz Mayıs Üniversitesi İlâhiyat Fakültesi Dergisi 2 (1987): 50; Hayrettin Nebi Güdekli, “Ebû Hâşim el-Cübbâînin Zât-Sıfat İlişkisine Yaklaşımı: Haller Teorisi” (Yüksek lisans tezi, Marmara Üniversitesi, 2008), 5. 
Fikrî açıdan Cüveynînin ikinci dönemini temsil eden el-Burhân fî usûli'l-fikh ${ }^{2}$ ve el-Akîdetün-Nizâmiyye adlı eserlerde hâller teorisi reddedilir. Buna karşın onun birinci dönemine karşıllı gelen ve Bâkıllânî̀nin kelâmî görüşlerinin etkisi altında kaleme alınan eş-Şâmil fî usûli'd-dîn ve el-İş̧âd adlı eserlerde ise hâller teorisi savunulur. Bu çalışmada, -el-İrşâd adlı esere yazılan şerhler de göz önünde bulundurularak-Cüveynînin, hâller teorisini savunan birinci dönem eserleri merkeze alınmıştır. Bununla beraber Cüveynînin öne çlkan öğrencilerinden Kiyâ el-Herrâsî (ö. 504/1110), Gazzâlî ve Ebü'l-Kâsım el-Ensârînnin ${ }^{3}$ (ö. 512/1118) eserleri de ana kaynak şeklinde bu çalışmada yerini almıştır.

Hâller teorisini konu alan veya içeren birçok modern çalışma mevcuttur. Bu çalışmalar içerisinde Richard M. Frank'in "Abū Hāshim's Theory of the 'States"' (1971) başlıklı makalesi olmak üzere birçok çalışması, Mehmet Dağ’ın "İmam el-Haremeyn el-Cüveynîde Nedensellik Kuramı" (1987), Orhan Şener Koloğlu'nun "Ebû Hâşim el-Cübbâînin Ahvâl Teorisi Üzerine Bazı Mülahazalar” (2007), Osman Demir'in “Cüveynî̀de Ahvâl Teorisi" (2008) adlı makaleleri, Hayrettin Nebi Güdekli'nin Ebû Hâş̧im el-Cübbâî̉nin Zât-Sıfat İlişkisine Yaklaşımı: Hâller Teorisi (2008) başlıklı yüksek lisans tezi, Hüseyin Kahraman'ın Cüveynîdde İlliyet Teorisi (2016) başlıklı doktora tezi, Jan Thiele'nin "Abū Hāshim al-Jubbā'î’s (d. 321/933) Theory of 'States' (ahwāl) and its Adaption by Ash'arite Theologians" (2016), Fedor Benevich'in "The Classical Ash'ari Theory of Ahwāl: Juwaynī and His Opponents" (2016) ve "The Rise of The Avicennian Ash'arite Metaphysics: Shahrastānī on Ahwāl and Existence" (2018) adlı makaleleri bu çalışmanın inşa edilmesinde önemli bir role sahiptirler. Bununla birlikte adı geçen çalışmalarda katılmadığımız bazı noktaları dipnotlar yoluyla açıklama gereğini hissettiğimizi belirtmeliyiz.

Söz konusu üç başlık altında kelâm atomculuğunun tümel modeli olan hâlleri değerlendirmeden önce önermeler bazında bu teoriyi genel hatlarıyla tanıtmakta yarar olacaktır. Eş'arîlerde hâller öne çıkan iki ana başlıkta değerlendirilir. Bunlardan birincisi illetli, diğeri ise illetsiz hâllerdir. ${ }^{4}$ İlletli hâller (el-ahvâlü’l-mü'allele), klasik

Cüveynînin el-Burhân fî usûli'l-fikh adlı eserinde yer alan fikrî değişim ve dönüşüm için bkz. Ömer Türker, "Bir Tümdengelim Olarak Şâhitle Gâibe İstidlâl Yöntemi ve Cüveynî’nin Bu Yönteme Yönelttiği Eleştiriler”, İslâm Araştırmaları Dergisi 18 (2007): 1-25; Ömer Türker, "Eş‘arî Kelâmının Kırılma Noktası: Cüveynînnin Yöntem Eleştirileri”, İslâm Araştırmaları Dergisi 19 (2008): 1-23.

3 Bu makalede kaynak olarak kullandığımız Ensârînnin Şerhu'l-İrşâd adlı eserinin çeşitli yazmaları mevcuttur. Ancak bu çalışmada iki ciltten oluşan bir nüshayı esas aldık. Bu nüshanın birinci cildi Princeton Üniversitesi'nde (Oversize Islamic Manuscripts, Garrett 634YQ) ve ikinci cildi de Süleymaniye Kütüphanesi'nde (Laleli 2247) kayıtlıdır.

4 İlletli ve illetsiz şeklinde ikili ayrım için bkz. Yusuf Şevki Yavuz, "Ahvâl”, DİA, II, 190-92. Özellikle Eş'arî kelâmı içerisinde hâller teorisini savunanların yaptığı bu ayrım için bkz. Richard M. Frank, "Al-Ahkām in Classical Ash'arite Teaching”, Classical Islamic Theology: The Ash'arites, Texts and Studies on the Deve- 
kelâm ontolojisine paralel olarak hâdis âlemde cevherler ve arazlar arasındaki taşıma ilişkisiyle açığa çıkar. Bu bağlamda "a-cevheri âlimdir"5 önermesi tahlile tabi tutulduğunda bu önermenin metafizik açıklaması, "a-cevheri ilim-1 arazını taşıdığından dolayı âlimdir” şeklinde karşılık bulur. Bu önermenin açıklayıcı cümlesinde a-cevheri ile ilim-1 arazı gibi iki tikel gerçek varlık yer alır. Bu tikel varlıklar, somut bir şekilde dış dünyada vardır. Bunlardan a-cevheri taşıyan, ilim-1 arazı ise söz konusu cevher tarafından taşınan somut niteliktir. Bunlar arasında cereyan eden taşıma ilişkisi neticesinde somut niteliğin taşıyıcısı konumundaki a-cevheri, "âlim olma” hâliyle nitelenir. Söz konusu önermede nitelenen konumundaki a-cevherinin "âlim olma/âlimdir" hâline sahip oluşu, taşıma ilişkisinden kaynaklıdır. Çünkü ele alınan "a-cevheri âlimdir" önermesine "neden a-cevheri âlimdir?" şeklinde soru yöneltilerek açıklayıcı cümle talebinde bulunulabilir. Bu soruya verilen muhtemel yanıt ise önermedeki öznenin ilim-1 arazı gibi somut nitelik taşımasıdır. Dolayısıyla "âlim olma" hâl ve sıfatını a-cevherine kazandıran ilim-1 arazı olduğu için bu araz, hâller teorisyenlerinin terminolojisinde "illet" adını alır, bundan dolayı ortaya çıkan hâl ise "malûl" olarak adlandırılır. Bu yönüyle kelâmî önermeler arasında "neden" sorusuna muhatap olan yüklemler, yani hâller illetli hâller adı altında toplanır. ${ }^{6}$

İlletsiz hâller ise önermelerde açıklama gerektirmeyen ve "neden" sorusuna muhatap olmayan sifatlardır. Bu sifatlar hakikat, tanım (had), hâssiye ve nefsî sıfat şeklinde de isimlendirilmektedir. ${ }^{7}$ Mesela "a-cevheri yer kaplayandır (mütehayyiz)" önermesinde yer alan yüklem, illetsiz bir hâli gösterir. Bu önermede yer alan özneye söz konusu yüklemin uygulanmış olması (haml) taşıyıcılık ilişkisinden kaynaklanmaz. Bu bağlamda "a-cevheri yer kaplayandır" önermesine "neden a-cevheri yer kaplayandır?” şeklinde bir soru yöneltilemediğinden bu tür sıfatlar, illetsiz hâller diye

lopment and History of Kaläm III, Richard M. Frank, ed. Dimitri Gutas (Hampshire: Ashgate Variorum, 2008), 770-777; Hüseyin Kahraman, “Cüveynîde İlliyet Teorisi” (Doktora tezi, Marmara Üniversitesi, 2015), 166-76.

5 Bu makalede ortak bir dil oluşturma ve dil kargaşasının önüne geçmek adına hâdis âlemdeki tikel gerçeklikler harf ve rakamlarla simgelenmiştir. Örneğin tikel bir ilim arazını "ilim-1 arazı" şeklinde rakamsal, bu arazın taşıyıcısı olan tikel cevheri ise "a-cevheri” şeklinde harf yoluyla ifade ettik. Böylece hâdis âlemdeki zâtların belirli ve tikel olduğunu vurgulamaya çalıştık. Çünkü birer tümel yüklem olan hâller sadece tikellere uygulanır.

6 İlim-1 araz gibi bir arazın a-cevheri tarafından taşınması sonucu açığa çıkan "âlim olma" hâli ve nedensellik ilişkisi, ateşin pamuğu yakmasındaki nedensellik şeklinde algılanmamalıdır (Ebü’l-Kâsım el-Ensârî, Şerhu'l-İrşâd, I, Garrett 634Yq, 46a). Ahvâl konusundaki nedensellik (illiyet) gerçek ve tikel somut bir özelliğin (ilim-1) soyut sayılabilecek bir hâli gerektirmesidir. Bu da "lüzûmiyyet" şeklinde yorumlanmaktadır. Hâllere dair "lüzûmiyyet" kaydı için Bkz. Cüveynî, eş-Şâmil fî usûli'd-dîn, thk. Richard M. Frank (Tahran: Müessese-i Mütâlaât-1 İslâmî Dânişgâh-1 McGill Şu’be-i Tehrân, 1981), 28.

7 Dönemin Eş‘arîlerine göre bu kavramlar eşanlamlıdır. Bkz. Richard M. Frank, "The Ash'arite Ontology: Primary Entities”, Classical Islamic Theology: The Ash'arites, Texts and Studies on the Development and History of Kalām III, Richard M. Frank, ed. Dimitri Gutas (Hampshire: Ashgate Variorum, 2008), 178. 
adlandırılır. Nefsî sıfatların yer aldığı önermelerin açıklayıcı cümlesinin olmayışına dair Cüveynî şöyle işarette bulunur:

Eğer "Emrin hakikatini dile getirdiniz. Peki emir neden emirdir?" diye sorulursa, biz de deriz ki: Emrin emir oluşu zâta dayalı bir vasıftır (vasfun yercíu ilâ zâtihi). O da herhangi bir illetle illetlenmeyen ve iradeyle ilişkilendirilmeyendir. Sana "Emir neden emirdir?" denildiğinde, buna en sağlam cevabın "Emir ancak kendinden dolayı emirdir" sözü olmalıdır. ${ }^{8}$

Kelâm geleneğinde cevherler için "yer kaplama” veya "bölünmeye kâbil olmama" ortak bir sıfat, illetsiz hâl ve hakikattir. Aynı şekilde farz edelim a-cevheri tarafından taşınıyor olan ilim-1, irade-1 ve kırmız1-1 gibi arazlar da ortak sıfatı illetsiz hâl ve hakikatlere sahiptir. Bu doğrultuda adı geçen arazlar için "araz olma" ortak bir hakikat ve birleşme zeminidir. Ne var ki, bunların her biri sırasıyla "ilim olma”, "irade olma" ve "kırmızı olma" adındaki illetsiz hâller üzerinden ayrışmaktadır. Cevherler gibi arazların da illetsiz hâllere sahip olduğu bilgisinden hareketle yukarıdaki pasajda yer alan "emir" örneğini ele alalım. Her araz, illetsiz hâl ve hakikate sahip olduğuna göre, hâdis âlemde bir araz türü olarak görülen kelâm da "araz olma" ile "kelâm olma" adında geniş ve dar kaplamlı illetsiz hâle sahiptir. Bu bağlamda kelâm türlerinden biri olan emrin "emir oluşu" için illet arayışı söz konusu olmaz.

Kelâm atomculuğunun tümel modeli olarak yorumlanabilecek hâlleri "şekil”, "kapsam" ve "yer" açısından ele almadan önce bu teoriyle beraber asgari düzeyde "zât" ve "sıfat" kavramlarının anlam genişliğine uğradığına değinilmelidir. Zira bu teoriyi benimseyen kelâmcılarla birlikte zât ile sıfat kavramları hâller merkeze alınarak yeninden yorumlanmıştır. Şöyle ki, hâller ile sıfatlar en azından Cüveynîye göre eşanlamlıdır. Hâller teorisiyle beraber yeni bir kelâmî terminolojisinin ortaya çıktığı söylenebilir. Zira bu teoride hâller merkeze alınarak kelâm literatürünün ağırlık merkezini oluşturan zât ile sıfat kavramları anlam genişliği kazanmıştır. Şimdi bu terminoloji farklılığını önermeler ekseninde izah etmeye çalışalım.

Hâlleri reddeden Cüveynî öncesi kelâmcllar nezdinde “a-cevheri âlimdir” önermesinin metafizik açıklaması, "a-cevheri ilim-1 arazını taşıdığından dolayı âlim adını almıştır" şeklindedir. Bu önermenin açıklayıcı cümlesinde iki gerçek varlık (a-cevheri ve ilim-1 arazı), bir nedensellik (“dolayı" bağlacı), bir de ad (“âlim” ismi) yer almaktadır. Bu kesim, hâlleri -yani kelâmî tümelleri- reddettiği için söz konusu önermenin yüklemini temsil eden "âlim" terimine dilin ötesinde bir değer vermez. Bu bağlamda onlar için "âlim" ifadesi ortak bir sıfatı ve sabiti göstermez, bilakis sadece a-cevherinin ilim-1 arazını taşıdığını bildirir. Dolayısıyla hâlleri reddedenlere göre 
birtakım kelâmî önermelerin yüklemleri salt sözcükten ibaret kabul edildiği için sıfat şeklinde bir değere haiz değildir. Buna göre "a-cevheri âlimdir” önermesinde açı̆̆a çıkan a-cevheri zât ve bu zâtın taşıdığı ilim-1 arazı ise gerçek anlamda sıfat kabul edilir. Başka bir ifadeyle, ilim-1 gibi tikel gerçekliğe sahip olan araz, "sıfat" kategorisinde yer alır. Buna karşın Cüveynî gibi hâller teorisini benimseyenler, ilim-1 arazını ancak mecazen "sıfat" sayarlar. ${ }^{9}$ Çünkü onlara göre ilim-1 gibi somut gerçekliğe sahip olan varlıkların ortak sıfat olma imkânı yoktur.

Bu bağlamda Cüveynî için yukarıdaki "a-cevheri âlimdir” önermesinin metafizik açıklaması "a-cevheri ilim-1 arazını taşıdığından dolayı âlim sıfatını almıştır” şeklindedir. Bu açıklamada iki gerçek varlık (a-cevheri ve ilim-1 arazı), bir nedensellik ("dolayı" bağlacı), bir de illetli hâl, yani manevî sıfat (âlim) açığa çıkar. Cüveynî için ilim-1 arazı a-cevherinin sıfatı değildir, a-cevherine manevî bir sıfat olan "âlim olma" hâlini kazandıran illettir. Arazlar, bu bakış açısıyla "sıfatlar" kapsamından çıkartıldığından dolayı bir diğer kategori olan "zât" kapsamına dâhil edilmiştir. ${ }^{10}$ Böylece hâdis âlemde hem cevherler hem de cevherler tarafından taşınan arazlar zât kategorisinde değerlendirilmiştir. Arazların da cevherler gibi birer zât sayılması "her zü’l-hâl zâttır (her hâl sahibi zâttır)" 11 genellemesinin kabulüne dayanır. Çünkü "a-cevheri âlimdir" önermesinde açığa çıkan a-cevheri ve bu cevherin taşıdığı ilim-1 arazı hâllerin bir diğer çeşidi olan illetsiz hâllerle nitelenir. Bu açıdan "a-cevheri yer kaplayandır" ve "ilim-1 arazdır” önermelerinin yüklemleri birer illetsiz hâli, hassiyeyi, hakikati, tanımı ve nefsî sıfatı temsil eder. Bâkıllânî ve Cüveynî için hâdis âlem kapsamında yer alan "cevher" adındaki kelâm atomları hem illetli (kırmızı olma ve âlim olma) hem de illetsiz (yer kaplama) hâllerine sahiptir. Buna karşın cevherler tarafından taşınan arazlar ise (kırmızı-1 ve ilim-1) başka bir arazı taşıma potansiyeline sahip olmadığı için sadece illetsiz hâllerle nitelenebilir. Bu noktadan hareketle hâlleri reddeden dönemin Eş'arîleri, "zât” ifadesiyle cevherleri, "sıfat” ifadesiyle de arazları kastederek temelde iki tikel kategoriyi esas alırlar. Ne var ki hâlleri savunan Eş‘arîler, "sıfat" ifadesiyle somut gerçekliğe sahip olmayan hâlleri, "zât" ifadesiyle de somut gerçekliğe sahip olan cevher ve arazları kastederler. Böylece temelde zâtlar, yani cevher ve arazlar ile sıfatlar, yani illetli ve illetsiz hâller olmak üzere iki temel kategori esas alınır.

Hâdis varlığa dair dönemin Eş'arî düşüncesindeki bu esas ayrım, temel mantık açısından kadim varlık alanına da yansımıştır. Bu bağlamda hâl karşıtı Eş‘arîlere

9 İbnü'l-Emîr, el-Kâmil fî usûli'd-dîn fî ihtisâri'ş-Şâmil fî usûli’d-dîn, thk. Cemâl Abdünnâsır Abdülmün'im, II (Kahire: Dâru's-Selâm, 2010), 722-23.

10 Richard M. Frank, “The Ash'arite Ontology”, 169.

11 Hâl sahibi veya hâllerle nitelenen varlıkların zü'l-hâl şeklindeki tabir için bkz. Kiyâ el-Herrâsî, Usûlü'd-dîn, Dâru'l-Kütübi'l- Misriyye, Kelâm 290, 84a. 
göre “Tanrı âlimdir” önermesinin metafizik açıklaması “Tanrı'nın zâtı ilim manasını taşıdığından dolayı âlim adını almıştır” şeklindeki cümledir. Bu açıklayıcı cümlede iki tikel varlık (Tanrı'nın zâtı ve ilim manası), bir nedensellik (“dolayı" bağlacı), bir de "âlim” adı yer alır. Bu bağlamda hâl karşıtı Eş'arîler için “Tanrı'nın zâtı” zât, sahip olduğu "ilim mânâsı" da sıfat kategorisinde yer alır. Söz konusu önermede yer alan "âlim" terimi ise bir tikel varlık olan Zât-1 ilâhînin bir diğer tikel nitelik olan ilim manasına sahip olduğunu bildiren bir sözcükten başka bir şey değildir. Diğer bir ifadeyle, söz konusu önermenin hem öznesi hem de yüklemi aynı müsemmayı gösterir. ${ }^{12}$ Ne var ki, hâlleri savunan Bâkıllânî ve Cüveynîye göre “Tanrı âlimdir” önermesinin metafizik açıklaması, “Tanrı'nın zâtı ilim manasını taşıdığından dolayı âlim sıfatını almıştır” şeklindedir. Önermenin bu açıklamasında iki tikel varlık (Tanrı'nın zâtı ve ilim manası), bir nedensellik ("dolayı” bağlacı), bir de illetli hâl (manevî sıfat olan "âlim") ortaya çıkar. Bu açıklama ışığında "Tanrı âlimdir" önermesindeki yüklemi temsil eden "âlim” terimi ne Tanrı'nın zâtını ne de zât tarafından taşınan ilim mânâsını gösterir. Bu terimin gösterdiği müsemma, aritmetik çokluğa tabi olmayan ve kadim ile hâdis ayrımlarının ötesinde kabul edilen ortak bir sıfattır. Cüveynî şârihlerinden Şerefüddin Tilimsânî el-Fihrî (ö.644/1246) hâl karşıtları ile hâl savunucularının zât-sıfat kavramlarıyla kastettikleri şeye dair şunları aktarır:

Bil ki, kelâmcılar, hâlleri kabul edenler ve reddedenler olmak üzere iki kısma ayrılırlar. [i] Kâdî [Bâkıllânî (ö. 403/1013)] ve İmâm [el-Haremeyn Cüveynî] gibi hâli kabul edenlerin sıfatlara dair kullandıkları ibare şöyledir: "Yaratıcı Teâlâ, hayatla hay (hayyun bi-hayâtin), ilimle âlim, iradeyle mürîd, kudretle kâdir, kelâmla mütekellim ve sem'le işiten, basarla da görendir -sem've basardan kasıt duyular değil, idrakin kendisidir-.

Dolayısıyla, onlar, bunları mevcut zât(lar) olarak kabul ederler. Bu zâtlar ise ilim, kudret ve iradedir. Ayrıca manaların zât tarafında taşınması nedeniyle zâtta birtakım hâllerin sabit olduğunu savunurlar. Bu da nitelemenin düşünceye konu olan tarafıdır. Böylece, ortaya çıkan hâlleri âlim olma, kâdir olma (vb.) şeklinde tabir ederler. Onlar, hâlleri varlıkla nitelemezler, aksine mutlak sübut (mahdü's-sübût) şeklinde ifade ederler. [ii] Hâlleri reddeden [Eş'arîler]in kullandıkları ibare ise şöyledir: "Allah âlimdir ve O'nun ilmi de vardır (ve lehu ilmun), kâdirdir ve O'nun kudreti de vardır” (...) Onlar, Allah'ın âlim oluşunu ilme sahip olmasıyla açıklarlar. Çünkü onlara göre hariçte zât ve zâtın sahip olduğu sıfat dışında bir şey yoktur. [Onlar, bu açıklamayla] hâlleri reddetmiş olurlar. Mevsûftan bahsedildiğinde ona zât, manadan bahsedildiğinde ona ilim ve kudret denilir. Manaya sahip olma bakımından zâttan bahsedildiğinde ise O'na

12 Ebü’l-Hasan el-Eş‘arî’nin (ö. 324/935-36) kelâm sistemini hâl karşıtı minvalinde değerlendiren İbn Fûrek (ö. 406/1015) "âlim” yüklemini "âlim olarak adlandırılmaya hak kazanan (istihkâk)" şeklinde açıklar. O, bu açıklamayla söz konusu yüklemin öznesinden başka (zâid) bir müsemmayı (hâli) göstermediğine işaret eder. Bkz. İbn Fûrek, Mücerredü Makâlâti'ş-Şeyh Ebi'l-Hasan el-Eş'arî, thk. Ahmed İbrahim es-Sâih (Kahire: Mektebetü's-sekâfeti'd-dîniyye, 2005), 319; Cüveynî, eş-Şâmil fi usûlidd-dîn, thk. Ali Sâmî en-Neşşâr Ali Sâmî en-Neşşâr, Süheyr Muhammed Muhtâr ve Faysal Bedir Avn (İskenderiye: Münşeâtü'l-Maârif, 1969), 636. 
âlim ve kâdir denilir. Dolayısıyla düşünceye konu olan iki, kullanılan tabirler ise üçtür. Mu'tezile ise söz konusu manaları kabul etmemiş ve Yaratıcı Teâlâ'nın kendiliğinden (li-nefsihi) hay, âlim ve kâdir olduğunu söylemiştir (...) $)^{13}$

Yukarıdaki pasaj bağlamında hâller teorisini benimseyenler için araz türleri ve ilâhî manaların "zât" şeklinde tabir edildiği görülmektedir. Ancak önemle belirtilmelidir ki, hâl savunucularının ilim-1 arazı gibi bir araza "zât" tabirinde bulunurken, onunla kendi başına kaim olan (mâ yekûmu bi-nefsihi) anlamını kastetmezler, aksine asıl maksatları bunların önermelerde zü'l-hâl şeklinde konu olmalarıdır.

Cüveynî ve öncesi Eş‘arî kelâm geleneğinin zât ve sıfat kavramlarından neyi kastettiklerini “Tanrı âlimdir” önermesi üzerinden izah ettikten sonra, detaylara inmeden buna paralel şekilde Mu'tezile geleneği için kısa bir parantez açmakta yarar olacaktır. Eş‘arî geleneği gibi bu gelenek de hâl karşıtları ve hâlleri savunanlar olmak üzere iki grupta ele alınabilir. Hâl karşıtları için “Tanrı âlimdir” önermesinde yer alan hem özne hem de yüklem aynı müsemmayı, yani Tanrı'nın zâtını gösterir. ${ }^{14}$ Oysa Ebû Hâşim gibi ahvâl teorisini ilk ortaya atan biri tarafından söz konusu önermede yer alan yüklemin Tanrı'nın zatından "başka” bir sabiti gösterdiği savunulur. O da hâldir. Kelâm literatürüne özgü bir tabirle, Ebû Hâşim’e göre söz konusu önermenin yüklemini simgeleyen "âlim" terimi sözcükten ibaret değildir ve nitelediği zâta zâiddir. Her ne kadar bu terim Ebû Hâşim düşüncesinde bir hâli gösteriyor olsa da, onun açıklama tarzı Bâkıllânî ve Cüveynînnin açıklama tarzından farklıdır. Ona göre Tanrı'nın âlim oluşu tikel bir varlık olan ilim manasından kaynaklı değildir. Aksine Tanrı'nın bu zâid sıfatı, zâta dayanan bir sıfattır. ${ }^{15}$ Böylece Tanrı için "âlim olma”

13 Şerefeddîn Tilimsânî el-Fihrî, Şerhu'l- Lüma i’l'l-edille, thk. Nizâr Hammâdî (Kuveyt: Darü'z-Ziyâ, 2018), 174; krş. Cüveynî, eş-Şâmil (Neşşâr vd.), 174. Arazlar ile ilâhî manalara "zât" tabirinde bulunulduğuna dair ayrıca bkz. Ensârî, Şerhu’l-İrşâd, I, 46a. Hâl savunucularına göre kelâmî atomlar olan cevherlerin yanında, arazların da zât kapsamına girdiği ve bunlardan her birinin nefsî sıfatlara (illetsiz hâller) sahip olduğu hususu için bkz. Richard M. Frank, "Abū Hāshim’s Theory of the 'States': İts Structure and Function”, Early Islamic Theology: The Mu'tazilites and al-Ash'arī, Texts and Studies on the Development and History of Kalām II, Richard M. Frank, ed. Dimitri Gutas (Surrey: Ashgate Variorum, 2011), 89-90.

14 Ebü'l-Hüzeyl el-Allâf'ın (ö. 235/849-50 [?]) “Tanrı âlimdir” önermesini “Tanrı bir ilimle âlimdir, ama o ilim bizzat O’dur (hüve âlimün bi-ilmin hüve hüve)” şeklinde açıkladığı Ebü'l-Hasan el-Eş'arî tarafından aktarılır. Bkz. Ebü'l-Hasan el-Eş'arî, Makâlâtü'l-İslâmiyyîn ve'htilâfü'l-musallîn, thk. Naîm Zerzûr, I (Beyrut: el-Mektebetü'l-Asriyye, 2005), 136. Ayrıca bkz. Richard M. Frank, "Attribute, Attribution and Being: Three Islamic Views", Classical Islamic Theology: The Ash'arites Texts and Studies on the Development and History of Kalām III, Richard M. Frank, ed. Dimitri Gutas (Hampshire: Ashgate Variorum, 2008), 453-454.

15 Zât-i ilâhî̀ye dair inşa edilen önermelerin yüklemleri açıklama gerektirir mi (hükümler muallel olabilir mi)? sorusunu Mu'tezile cenahı olumsuz, Eş‘ariyye cenahı ise olumlu yanıtlar. Bu bağlamda oldukça eleştirel bir yaklaşımla Ebû Hâşim’in sıfat anlayışını ele alan Cüveynî, “Tanrı âlimdir” önermesini tahlile tabi tutar. Ona göre söz konusu önerme Ebû Hâşim tarafından en özel vasıf olan (ehassü'l-evsâf) “kadim olma” hâlinden kaynaklıdır. Dolayısıyla Cüveynîye göre Ebû Hâşim'in düşüncesinde “Tanrı'nın zâtı kadim olma adındaki en özel vasfa sahip olduğundan dolayı âlimdir" şeklindeki açılama "Tanrı âlimdir" 
hâli Mu'tezile mezhebinin resmî görüşü olan "ilâhî manaların reddi” hususuyla uyumluluk arz eder.

Mu'tezile geleneğinin kadim varlık alanını gösteren söz konusu önermeye bakışı bu minvaldedir. Hâdis varlık alanındaki taksim ise Eş‘arîlerin hâller anlayışına nazaran daha karmaşık yapıdadır. Bâkıllânî ve Cüveynî’nin hâller anlayışının aksine Ebû Hâşim'e göre her araz onu taşıyan mahalle illetli bir hâl kazandırmaz. Mahallin diri olmasıyla (hay) koşullu olmayan arazlardan sadece oluş arazları (ekvân: hareket, sükûn, içtima', iftirâk ve telif) taşıyıcı cevherlerine hâl kazandırır. ${ }^{16} \mathrm{Bu}$ bağlamda "a-cevheri hareketlidir" önermesinin metafizik açıklaması "a-cevheri hareket-1 arazını taşıdığından dolayı hareketli olma hâlini almıştır” şeklindedir. Bu açıklamada iki tikel varlık (a-cevheri ve hareket-1 arazı) bir nedensellik ("dolayı" bağlacı), bir de illetli hâl (hareketli olma) açığa çıkar. Telif arazı hariç (bu araz makalenin "kapsam" başlığında ele alınacaktır), bu tür arazlar cismin yapıtaşı olan tek tek cevherlere hâl kazandırırken, cisimlerin bütünlügüne hâl kazandırmaz. Mahallin diri olmasıyla (hay) koşullu olan arazlar ise, cismin yapıtaşı olan cevherlerin yerine diri bünyeye/cisme hâl sağlar. Bu bağlamda Zeyd gibi diri bir bünye için dile getirilen "Zeyd âlimdir" önermesinin metafizik açıklaması "Diri olan Zeyd'in bünyesindeki a-cevheri ilim-1 arazını taşıdığından dolayı bu bünye âlimdir” şeklindedir. Böylece Ebû Hâşim düşüncesinde hâdis varlık alanında "âlim" hâli ilim-1 gibi bir tikel özelliğe bağlı olarak ortaya çıkarken (illetli hâl); aynı hâl kadim varlık alanında tikel özellik olan ilim manasına bağlı şekilde ortaya çıkmamaktadır.

Ebû Hâşim'in hâdis varlık alanındaki illetsiz hâllere bakışı Eş'arîlerde olduğu gibi cisimlerin yapıtaşı olan cevherler ve arazlarla sınırlıdır. ${ }^{17}$ Şu farkla ki, Eş'arîlerde ancak var olanların (mevcûd) nefsî sıfatından söz edilebilir iken, Ebû Hâşim düşüncesinde ise "şeyler" varlığa çıkmadan önce de nefs sıfatına (zât sıfatı/en özel vasıf) sahiptir. Başka bir deyişle, Bâkıllânî ile Cüveynî için her hâl sahibi mevcut olabilir. Oysa Ebû

önermesinin metafizik açıklayıcısıdır. Böylece Cüveynî’nin yorumuna göre bir hâl (kadim olma) başka bir hâle (âlim olma) yol açtığından dolayı Ebû Hâşim’in sıfat anlayışı da illetlerle açıklanmış olur. Bu da Cüveynî tarafından Mu'tezile'nin sıfat anlayışında bir tutarlılı̆̆ın olmadığı şeklinde yorumlanır. Cüveynî, eş-Şâmil (Neşşâr vd.), 705. Ancak Zât-i ilâhî için "kadim olma" ile "âlim olma" hükümleri arasındaki "illiyet" ilişkisinin daha derin sorgulanması gerekir. Nitekim Mu'tezilî metinlerde zât sıfatı (kadim olma) ile zâtî sıfatlar (âlim olma) arasındaki ilişki "istihkâk", "iktizâ" ve "vücûb” kavramıyla açılanır (Kâdî Abdülcebbâr, el-Mecmû'fi'l-Muhît bi't-teklîf, I, thk. Jean Yusuf Houben [Beyrut: el-Matbaatü'l-Katûlikiyye 1965], 152; Kâdî Abdülcebbâr, Şerhu'l-Usûli'l-hamse, thk. Abdülkerim Osman [Kahire: Mektebetü Vehbe, 1996], 129, 199; İbnü'l-Melâhimî, Kitâbu'l-Mu'temed fî usûli'd-dîn, thk. Martin McDermott ve Wilferd Madelung [Oxford: el-Hoda, 1991], 183). Bu da söz konusu iki sıfat arasında illiyet ilişkisinden çok, epistemik açıdan kaplam genişliği ve darlığına dayalı bir adlandırmanın olduğunu çağrıştırır. 
Hâşim illetli hâlleri varlık alanına taşırken, illetsiz hâl, hakikat, tanım ve hâssiyeyi varlık öncesi zâtlar alanına taşımaktadır.

Hâl savunucuları genel ontoloji şemalarını hâlleri merkeze alarak düzenler. Buna göre onların ontolojisinde ilk olarak zâtlar ve sıfatlar (illetli hâller-illetsiz hâller) şeklinde ikili bir ayrım öne çıkar. Zâtlar başlığının altına cevherler ve ilâhî zât ile arazlar ve ilâhî manalar girerken, sıfatların altına ise -illetli olsun veya olmasın- bütün hâller girer. Burada zâtların kapsamına giren varlıklar tikel gerçekliği temsil ederken, sıfatların kapsamına giren hâller tümel niteliklerden ibarettir. ${ }^{18}$

Bâkıllânî et-Temhîd gibi ilk dönem eserlerinde hâller teorisini reddederken, Hidâyetü'l-müsterşidîn ve en-Nakzü'l-kebîr gibi eserlerindeyse bu teoriyi savunduğu -Cüveynînin aktardığı kadarıyla- anlaşılmaktadır. Cüveynî, eş-Şâmil, (Neşşâr vd.), 630. Ayrıca bkz. Jan Thiele, “Abū Hāshim al-Jubbā’î̀s (d. 321/933) Theory of 'States' (ahwāl) and its Adaption by Ash'arite Theologians", The Oxford Handbook of Islamic Theology, ed. Sabine Schmidtke (Oxford: Oxford University Press 2016), 379. Bâkıllânî’nin bu teoriye farklı yaklaşımlarını "hem ahvâlin reddi hem de kabulü sadedinde sıfatlar ispata kabildir" şeklinde yorumlayan Cüveynî, el-İrşâd’dan önce kaleme aldığı eş-Şâmil’de Eş‘arî kelâmındaki sıfatlar konusunu her iki yöntemle de ele aldığı belirtilmelidir. Ne var ki, el-İrşâd'da sadece hâller yöntemi üzerinden sıfatlar konusuna yaklaşır. Dolayısıyla eş-Şâmil gibi kapsamlı bir eserde Cüveynînnin hangi noktalarda Eş'arî mirasının aktarıcısı veya bu görüşlerin benimseyeni olduğuna dikkat edilmelidir. Bu bağlamda söz konusu teori savunulunca "hâller" başlığı dışında başka bir sıfat kategorinden söz edilemez. Dolayısıyla bir şey ya zâttır (cevherler-arazlar ve Zât-i ilâhî-O'nın manaları) ya da sıfattır (illetli hâller ve illetsiz hâller). Cüveynî gibi bir Eş'arî hâl savunucusunun konuya yaklaşım tarzı böyle iken, "Tanrı vardır" önermesinde yer alan yüklemin illetsiz hâl olmadığı, aksine nefsî bir sıfat olduğu iddiasının hatalı olacağı kanaatindeyiz. Cüveynî için her nefsî sıfatın illetsiz bir hâle karşılık gelmediğini savunan Fedor Benevich, iddiasını eş-Şâmil’e referansta bulunarak temellendirmeye çalışır; Fedor Benevich, "The Classical Ash'ari Theory of Ahwāl: Juwaynī And His Opponents”, Journal of Islamic Studies 27.2 (2016): 143-144. Bu referans için bkz. Cüveynî, eş-Şâmil (Neşşâr vd.), 308. Ancak ilgili referanstan böyle bir sonuca varmak oldukça güçtür. Çünkü hâller savunulsa da savunulmasa da Eş‘arî düşüncesinde "a-cevheri vardır" ve "Tanrı vardır" önermelerinde yer alan yüklemler önermenin konusunu gösterir. Başka bir ifadeyle "var" (mevcûdün) ile zât (cevherler-arazlar ve Zât-i ilâhî-O'nın manaları) eş anlamlıdır. Varlığın herhangi bir şekilde gerçek sıfat kabul edilmesi mütekaddimîn Eş‘arî kelâm sistemini Mu'tezile cenahında geniş çapta kabul gören "varlık öncesi zâtlar" (ma'dûmun şeyiyyeti) teorisine götürür. Bu bağlamda Cüveynî eş-Şâmil'de altı noktada "varlık/vücûd" adında bir sıfatın olmaması gerektiğini belirtir ve el-İrşâd'da da bu sıfatın “sözde sıfat” (tevessü'an) olduğunu vurgular: Cüveynî, Kitâbu'l-İrşâd ilâ kavâtı 'ìl-edille fì usûli'l-i'tikâd, thk. Muhammed Yûsuf Mûsâ (Kahire: Mektebetü'l-Hancî, 1950), 31; Cüveynî, eş-Şâmil (Neşşâr vd.), 177 vd., 576; Ebü'l-İzz el-Muktarah, Şerhu'l İrşâd, thk. Nezihe Ma'ric, I (Lübnan: Dâru İbn Hazm 2014), 222. Evet, dönemin Eş‘arî kaynaklarında vücûdun bir sıfat şeklinde yorumlanmasına yol açan ibarelerle karşılaşılır. Ancak bu ibareler Cüveynînin düşünce sistemi bütünlüğü içerisinde değerlendirilmeye muhtaçtır. Bu bağlamda Richard M. Frank sıfatları gerçekliğe sahip (in realm of the real/metaphysics) ve sözcükten ibaret (in realm of words/logic) şeklinde ikiye ayırır. Vücûd gibi bir ifadenin mevcutlar için ortak değer şeklinde algılanması aslında sözcüklerin ötesine geçmemektedir; bkz. Frank, “The Ash'arite Ontology”, 177. Ensârînin "vücûd” sıfatılla ilgili "her mevcûda uygulanabilen ibare/el-ibâretü's-sâlihetü li-külli mevcûdin” şeklindeki tabiri de bu yorumu destekler niteliktedir; bkz. Ensârî, Şerhu'l-İrşâd, I, 42b. Ayrıca ilgili referansta "Size göre nefs sıfatı nedir?" sorusu yer alır. Bu sorudaki "siz" zamirinden kasıt sadece Bâkıllânî ve Cüveynî değildir. Bir bütün olarak dönemin Eş'arîleridir. Dolayısıyla Eş'arîler için hâller savunulmasa da "nefsî" sıfatlardan söz edilebilir. Ancak bu sıfatlar zâtlardan ibaret kabul edildiğinden ontik bir değere haiz değillerdir ve "sözde" sıfatın ötesine geçememektedir. Kısacası hâller savunulmadığı takdirde "a-cevheri yer kaplayandır, vardır, hâdistir" yüklem ve hükümleri ontik zeminde a-cevherinden başka bir şey değildir. 


\section{Hâllerin Şekli}

Kelâm atomculuğunun tümel modeli olan hâllere birtakım aksiyomlar atfedilir. $\mathrm{Bu}$ aksiyomlar hâller teorisinin çerçevesini belirler. Belirlenen bu çerçeve neticesinde Bâkıllânî-Cüveynî eksenindeki hâller teorisi bazı noktalarda hem Ebû Hâşim el-Cübbâ̂’nin benimsediği teoriden hem de felsefî tümel modellerinden ayrışır. Bu aksiyomlar şunlardır:

Aksiyom-1: Haller zâtın kendisi değildir. Kelâm ontolojisi içerisinde gerçek önermeler tikel özneler ve tümel yüklemlerden oluşur. Bu bağlamda "a-cevheri âlimdir" önermesini oluşturan özne somut bir gerçekliği, yüklem ise tümel bir sabiti gösterir. Yüklemin sözcükten ibaret olmayışı ve ortak bir sıfatı göstermesi hâl teorisyenlerinin temel iddiasıdır. Dolayısıyla aksiyom-1 gereği söz konusu önermede yer alan yüklemin gösterdiği sabit, hâdis âlemde ilim arazlarını (ilim-1, ilim-2, ilim-3...) taşıyan her bir cevher (a-cevheri, b-cevheri, c-cevheri...) için ortak bir sıfatı temsil eder. Başka bir ifadeyle önermenin yüklemi a-cevherini değil, bu cevherin ötesinde aritmetik çokluğa tabi olmayan ortak "bir" sabiti gösterir. Kelâmî gelenek içerisindeki teknik tabirle söylenecek olursa hâller, uygulandığı zü'l-hâllere zâiddir.

Hâller teorisini reddeden Cüveynî öncesi kelâmcılar "a-cevheri yer kaplayandır" gibi bir önermede sadece önermenin öznesini gerçeklik (hakikat) şeklinde kabul ederler. Bu bağlamda onlara göre "yer kaplayan" yüklemi ancak a-cevherini gösterir. Dolayısıyla ortada tek bir gerçeklik vardır, o da a-cevherinden başka bir şey değildir. Ancak hâlleri benimseyenlere göre aksiyom-1 kabul edilmediği takdirde inşa edilen birtakım önermeler anlamsız olacaktır (totoloji). Çünkü hem özneyi hem de yüklemi simgeleyen terimlerin sadece a-cevherini gösterdiği iddia edildiğinde "a-cevheri yer kaplayandır" önermesi "a-cevheri a-cevheridir” formatına denk düşer. Bu da önermelerin anlamsızlığıyla sonuçlanır. Aksiyom-1'e Cüveynî şu ifadelerle işarette bulunur:

Herhangi biri cevherin varlığını bildiği halde önce onun yer kaplama [özelliğinden] habersiz, ardından ise bu bilgiye vâkıf olabilir. Öyleyse o kişide cevherin varlığına ve yer kaplamasına dair ilimler bir arada bulununca, [tartışmada rakip olarak bilinen] hasım şu iki durumdan kurtulamaz: Ya her ikisinin de aynı bilgi olduğunu söyleyecektir, ki bu durumda şaşıp kalacaktır. ${ }^{19}$ Çünkü biz, yer kaplama [özelliği] bilinmediği halde cevherin varlığına dair bilginin sübut bulabileceğini kesin bir şekilde ortaya koyduk. Eğer yer kaplamaya dair bilgi ile cevherin varlığına dair bilgi aynı olsaydı, cevherin varlığı bilindiğinde yer kaplamasının bilinmemesi imkânsız olurdu. (...) Her ikisi kendi başına iki [farklı] bilgi olduğu ve biri bilinmeden diğerinin bilinebileceği ortaya

19 Yukarıdaki pasajın cümle akışında uyumsuzluk göze çarpmaktadır. Nitekim Arapça'da "immâ... ve immâ" kalıbı Türkçe'ye “ya... ya da” şeklinde çevrilir. Ne var ki, metnin Arapça aslında sadece tek "immâ” edatı yer alır. 
çıktıktan sonra, biz tartışmayı taksim edeceğiz. Deriz ki: Bu iki bilgi tek bir maluma mı, yoksa iki maluma mı ilişmektedir? Eğer hasım iki maluma iliştiğini iddia ederse; ona 'Bu malumlardan biri var olan cevherdir. Diğer malumu da bize gösterir misin?" diye soru yöneltilir. Böylece onun iddiası sarsılır ve cevherin varllğına zâid olan bir malumu gösterme dışında çaresi kalmaz. ${ }^{20}$

Hâller teorisini inşa etmedeki temel amacı "Tanrı âlimdir" gibi önermeleri anlamlı kılma olan Ebû Hâşim, aksiyom-1 sayesinde ilâhî sıfatlar problemini çözmeye çalışmıştır. Nitekim yukarıda da işaret edildiği üzere önermedeki özne ve yüklemi simgeleyen terimlerin aynı şeyi göstermesi anlamsız önerme inşasına yol açar. O da “Tanrı Tanrı'dır” gibi kendini tekrarlayan önerme yapısıdır. Bu aksiyom hem mezhep farklılığı bulunmaksızın bütün hâl savunucuları hem de realistler ${ }^{21}$ için geçerlidir.

Aksiyom-2: Birleşme ve ayrışma hâllerle sağlanır. Cevherler; "cevher olma”, "yer kaplama” veya "bölünmeye kâbil olmama” gibi illetsiz hâl ve nefsî sıfatlarla araz türlerinden ayrışır. Aynı şekilde kırmızı-1 ile mavi-1 arazları, her ne kadar "renk olma" hâlinde birleşseler de sırasıyla "kırmızı olma" ile "mavi olma" hâllerinde birbirlerinden ayrışırlar. Eğer aksiyom-2 reddedilirse tikellere uygulanan bu tür yüklemler kelimelerden ibaret kalır. Bu da özünde cevherlerin arazlardan ve araz türlerinin de birbirinden ayrışmasının salt yokluğa dayandırılması sonucunu doğurur. Dolayısıyla madem apaçık şekilde cevherler ile arazların birtakım niteliklerle birbirinden ayrıştığı biliniyor, bu durumda söz konusu nitelikler için varlıksal bir statü zorunlu konuma gelir. Cüveynînin el-İsşâd şârihlerinden Ebü'l-İzz el-Muktarah (ö. 612/1215) sözcükler üzerinden elde edilen genel-özel anlamlara dair tartışmayı şöyle tasnif eder:

Bu meseledeki tartışma, umum-husus (genel-özel) konusu etrafında döner. Çünkü biz [araz olan] siyah ve beyazın renk noktasında ortak olduğunu biliriz. Oysa ikisi de siyahlık ve beyazlık hususunda birbirinden farklıdır. Ortak oldukları hususun, farklılaştıkları husustan anlamca başka olması gerekir. İşte bu mevzuda insanlar üç gruba ayrılmıştır: Bir grup umum-hususun anlamların değil, sözcüklerin özelliği olduğuna yönelik fikir beyan etmiştir. Bunlara göre umumun anlamı bir sözcügün birçok müsemmayı kendi içine alabilecek kapasitede olması iken, hususun anlamı da bir sözcügün sadece bir müsemmaya tahsis edilmesi ve onunla sınırlı kalmasıdır. Bir diğer grup bu tür şeylerin sözcüklere ait kılınmasına karşı çıkmış, renkliliğin bir sıfat ve siyahlığın da başka bir sıfat olduğunu söylemiştir. Böylece siyah olarak adlandırılan arazın renk olma ve siyah olma şeklinde iki sıfatı bulunur. Kelâmcılardan üçüncü bir grup ise, bunları vücûh ve itibarlara indirgemiş ve bunların mevsuflara sıfat olabilirliğinden kaçınmışlardır. Ba-

20 Cüveynî, eş-Şâmil (Neşşâr vd.), 635.

21 Mesela idealizm için tespit edilen “Teklik aksiyomu” gereği “B gibi bir yüklemin gösterdiği bir ve yalnız bir tek B-lik ideası vardır. Bu ideaya B’nin kendisi denir” şeklindeki çıkarım önermelerdeki yüklemlerin öznelerinden "başka" olduğuna işaret eder. Bu aksiyom için bkz. Teo Grünberg ve David Grünberg, Metafizik, ed. İskender Taşdelen (Eskişehir: Anadolu Üniversitesi, 2010), 36. 
zen bunlar (üçüncü grubu kastediyor) 'itibarlar hakikatin bir parçasıdır', söyleminde bulunur. Felsefeciler ise bunların, zihnin ötesinde varlı̆̆ı olmayan, akıl ve zihne ait birtakım şeyler olduğunu ve mutlakların (el-mutlakât) zihnin ötesinde dış dünyada varlıkları bulunmadığını söylemişlerdir. ${ }^{22}$

Yukarıdaki pasajda aksiyom-2'ye işaret eden Muktarah, felsefî görüşü de ilave ederek "beyaz-1 renktir" önermesinde yer alan yüklemi dört ana grupta değerlendirir. Bunlar sırasıyla (i) sözcük, (ii) nefsî sıfat (illetsiz hâl), (iii) vücûh/itibar ve (iv) zihne ait varlıklardır. Bu görüşlerden ilk üçü kelâm geleneğine, dördüncüsü ise felsefe geleneğine aittir. Ancak söz konusu üçlü taksim Bâkıllânî ve Cüveynî için geçerli değildir. Nitekim onlara göre hâller teorisi ortaya çıkmadan önce bu tür sıfatlar "vücûh/itibar" şeklinde tabir edilmiş ve bu tür tabirlere başvuranlar örtük şekilde hâller teorisi kullanmıştır. ${ }^{23}$ Kısacası Bâkıllânî ve Cüveynî nezdinde kelâmcılar hâller teorisini kabul edenler ve etmeyenler olmak üzere iki gruba ayrılır.

Aksiyom-2 illetsiz hâl, hakikat ve nefsî sıfatlara dairdir. Bu aksiyoma göre varlıklar arasındaki birleşme ve ayrışma illetsiz hâllerle sağlanır. Dolayısıyla a-cevheri, b-cevheri ve c-cevherinin aynı (misl) oluşu, bütün nefsî sıfatlarda "bir" olmaya dayanır. ${ }^{24}$ Bu bağlamda Cüveynî ve öncesi hâl savunucularına göre kelâm geleneğinde gerçek tanımlar bu aksiyoma dayanılarak hâller üzerinden gerçekleşir. Nitekim felsefe geleneğinde tümeller, varlık ile kavramlar arasında birleşme ve ayrışmayı sağladığı

23 Mütekaddimîn Eş'arî kelâmcılardan İbn Fûrek ile Bâkıllânî, hâllerin Ebü’l-Hasan el-Eş'arî tarafından sistemin bir gereği olarak kullanılıp kullanılmadığı noktasında görüş ayrılığına sahiptir. İbn Fûrek, Ebü'l-Hasan el-Eş'arînnin düşünce sisteminde "a-cevheri hareketlidir” önermesindeki yüklemin (hüküm veya illetli hâl) özne olan a-cevherine zâid olmadığı (ve leyse kevnuhu müteharriken ekseru min zâtihi) yorumunda bulunur. Söz konusu önermede özne ile yüklemin aynı şeyi gösterdiği iddiası hâller teorisinin Ebü’l-Hasan el-Eş‘arî tarafından reddedildiği sonucunu doğurur: İbn Fûrek, Mücerred, 319. Oysa Bâkıllânîye referansta bulunan Cüveynî hâllerin örtük şekilde Ebü’l-Hasan el-Eş'arî tarafından kullanıldığına işaret eder: Cüveynî, eş-Şâmil (Neşşâr vd.), 631. Bu durumu Cüveynînnin öğrencisi Kiyâ el-Herrâsî, Bâkıllânî’den çarpıcı bir pasaj aktararak şöyle dile getirir: "Kâdî [Bâkıllânî] şöyle dedi: Hâlleri Şeyh Ebü'l-Hasan [el-Eş‘arî] kabul etmedi ve ben kabul ettim diye neden üstüme üstüme geliyorsunuz? [Oysa] bu bir yanılgıdır. Ebü’l-Hasan hâlleri kullanırdı ve onun kitapları hâllerle doludur. Çünkü o: 'Bir şey bir yönüyle bilinir başka bir yönüyle de bilinmeyebilir (kad yu'lemu'ş-şey'u min vechin ve yuchelu min vechin)' derdi. İşte bu, hâl savunusudur. Sadece o, yön (vecih) derdi biz ise hâl demekteyiz" (Kiyâ el-Herrâsî, Usûlü'd-dîn, 116b). "Vücûh" ve "itibar" kavramlarının hâllerin eşanlamlısı olduğunu savunan Bâkıllânîye açık ifadelerle Cüveynî de katılmaktadır (Cüveynî, el-İrşâd, s. 83). Ne var ki, el-İrşâd' ’n şârihlerinden Muktarah bu iddiaya katılmadığını dile getirir (Muktarah, Şerhu'l-İrşâd, I, 310-311). Bu kavramlarının Gazzâlî öncesi kelâmcılar ile Gazzâlî sonrası kelâmcılar için ne anlam ifade ettiği incelenmeye değer bir konudur.

24 İlletsiz hâller üzerinden sağlanan söz konusu birlik ve ayrışma dönemin kelâm literatüründe "mümâselet" ve "muhâlefet" kavramlarıyla karşılanmıştır. Bu kavramlardan özellikle "mümâselet"in "benzerlik" şeklinde çevrilmesinin isabetli olmadığı kanaatini taşımaktayız. Nitekim iki cismin birbirine müşabih olması (müşâbehet) "benzerlik" kavramıyla karşılanabilir. Ancak a-cevheri ve b-cevheri gibi iki tikel ve somut varlığın bütün nefsî sıfatlarda "bir” oluşu "benzerlik" kavramıyla açıklanacak gibi durmuyor. Çünkü a-cevheri ile b-cevheri her yönleriyle aynıdır. Dolayısıyla "mümâselet" kavramının "aynı olma" şeklinde karşılanması daha uygundur. 
için tanımların malzemesi sayıldığı gibi, kelâm atomculuğunun tümeller modeli olan hâller de benzer fonksiyonda değerlendirilmiştir.

Ebû Hâşim için bu aksiyom “zâtlar arasındaki aynı ve farklı olma ehassü'l-evsâf ile sağlanır” şeklindedir. Ebû Ali el-Cübbâîye (ö. 303/916) göre kadim zâtın hâdis zâtlardan farklılaşması, zât sıfatlarındaki "zorunluluk (vücûb)" kaydına dayanır. Şöyle ki, Zeyd ile Tanrı her ne kadar "âlim olma” vasfını paylaşsa da, Tanrı'nın sıfatları zorunluluk kaydı üzerinden Zeyd'in sahip olduğu sıfatla "bir” olmaz. Dolayısıyla Tanrı ile Zeyd’in birtakım önermelerin yükleminde "bir" şeklinde görünmesi tam bir birlik değildir. Ne var ki, Ebû Hâşim çeşitli gerekçelere dayanarak sıfatlara getirilecek "zorunluluk" kaydının yeterli olmadığını belirtir. Ona göre her zât ancak özgün bir sıfat üzerinden geri kalanlardan ayrışabilir. O, en özgün ve en özel sıfatı "ehassü'l-evsâf” veya "zât sıfatı" şeklinde tabir eder. ${ }^{25}$ Bu bağlamda Ebû Hâşim'e göre Tanrı'nın en özel vasfı "kadim olma" illetsiz hâlidir. Tanrı'nın zâtı bu sıfat üzerinden ötekilerden farklılaşır (muhâlefet) ve Tanrı bu sıfata zâtı gereği sahiptir (li-zâtihi). Âlim olma, kâdir olma, diri olma ve mevcut olma hâlleri ise bu sıfatın bir gereği (limâ hüve aleyhi fi-zâtihi) şeklinde farklı bir kavramın altında değerlendirilmiştir. ${ }^{26}$ Tanrı'nın sahip olduğu en özel vasıf da dâhil olmak üzere bu sıfatlar birer hâldir. ${ }^{27}$ Çünkü hâl savunucularına göre zâtlar arasındaki aynı olma (mümâselet) ve farklı olma (muhâlefet) illetsiz hâller üzerinden sağlanır. Şu farkla ki, Eş‘arî hâl savunucularına göre iki zâtın herhangi bir illetsiz hâlde denkleşmemesi "farklı olma" için yeterliyken, Ebû Hâşim ve takipçilerinin görüşüne göreyse söz konusu farklılık ancak en özel vasıfla ortaya çıkar. Dolayısıyla kadim zât, hâdis zâtlardan en özel vasıf üzerinden ayrışıyorsa, en özel vasfın da (zât sıfatı) adı geçen diğer vasıflar gibi hâl olması gerekir. Ebû Hâşim'e atfedilen sıfat taksimini Cüveynî’nin bakış açısıyla değerlendirmek gerekirse; zât sıfatı (kadim olma) ile zâtî sıfatların (âlim olma, kâdir olma, mevcut olma...) ayrı isimler altında ikili şekilde kategorileşmesi, bir bakıma yapay gibi duruyor. ${ }^{28}$ Çünkü Ebû Hâşim tatarafından Mu'tezile düşüncesine kazandırılmıştır. Bkz. Cüveynî, eş-Şâmil (Neşşâr vd.), 292-93.

26 Richard M. Frank, Beings and Their Attributes: The Teaching of Basrian School of the Mu'tazila in the Classical Period (Albany: State University of New York Press, 1978), 53.

27 Zât sıfatının da bir hâl olduğuna dair bkz. İbnü'l-Melâhimî, Kitâbu'l-Mu'temed, 183.9; Cüveynî, eş-Şâmil (Neşşâr vd.), 308.18.

28 Cüveynî, Mu'tezile'nin sıfatlarını dörtlü şekilde taksim eder. İlk iki başlı̆̆a da sırasıyla nefs sıfatları (illetsiz hâller) ile mana sıfatlarını (illetli hâller) yerleştirir (Cüveynî, eș-Şâmil, Neşşâr vd., 309-309). Öyle görünüyor ki, Mu‘tezile'nin sıfat anlayışını yorumlayan Cüveynî için kadim varlıkta zât sıfatı ile zâtî sıfatlar arasında ontik zeminde kayda değer bir ayrım söz konusu değildir. Dolayısıyla Ebû Hâşim için zât sıfatı olan "kadim olma" ile zâtî sıfat olan "âlim olma" arasında sadece kaplam farkı bulunuyor olabilir. Çünkü “âlim olma” hâli Zeyd’i de kapsar iken, "kadim olma” hâli ise sadece Tanrı'nı zâtı için geçerlidir. Ancak önde gelen Mu'tezile âlimlerine Cüveynî tarafından atfedilen bu sıfat taksiminin Mu'tezilî bakışı tam yansıtmadığını belirten Richard M. Frank, bu taksimin Cüveynînin mezhep kaygılarından 
rafından Tanrı'nın zâtı, "âlim olma" veya "kadîr olma” gibi sıfatlarla ötekilerden ayırt edilebilmiş olsaydı "zât sıfat"ına ihtiyaç duyulmazdı. Bu bağlamda zât sıfatı ile zâtî sıfatlar arasında ontik değer bakımından keskin bir ayrım bulunmaz. Ancak epistemik açıdan bu iki sıfat türü için lüzûmiyet ilişkisinden söz edilebilir. Nitekim bir zâtın en özel vasfı idrak edildiğinde zâtî vasıflar da beraberinde idrak edilir. Mesela a-cevheri tarafından taşınan siyah-1 arazı "siyah olma" adında en özel vasfa, yani zât sıfatına sahiptir ve bu sıfat üzerinden öteki zâtlardan farklılaşır (muhâlefet). Söz konusu arazın zât sıfatı idrak edildiğinde "renk olma”, "araz olma" ve "şey olma” gibi zâtî sıfatları da idrak edilmiş olur. Dolayısıyla bu iki sıfat türü arasındaki epistemik ilişki zaman zaman ontik bir ilişkiymiş gibi değerlendirilir. Başka bir ifadeyle, zât (kadim olma) ve zâtî (âlim olma, kâdir olma...) şeklindeki ayrım sırasıyla dar kaplamı (Tanrı) ve geniş kaplamı (Tanrı ve Zeyd) gösterme amacının bir sonucudur. Cüveynî̀nin el-İrşâd şârihlerinden Muktarah, zât sıfat ile zâta dayalı sıfatlar arasındaki bu ilişkiyi ehassü'l-evsâf konusu bağlamında klasik mantıktaki kavramlarla ilişkilendirir. Çünkü bir mahiyetin "düşünen" olduğu bilindiğinde, onun "insan", "canlı" ve "cevher" olduğu da bilinir. Muktarah bu ilişkinin lüzûmiyet ilişkisi olduğunu belirtip Mu'tezile düşüncesinde yer alan ehassü’l-evsâf görüşünün de klasik mantıktan ödünç alındığının altını çizer. ${ }^{29}$

Aksiyom-3: Hâller varlıksaldır. Hâllere dair zikredilen bu aksiyom, daha çok Eş'arî cenahın düşünce sistemi için geçerlidir. Nitekim bu düşünce sisteminde nitelikler hâdis âlemde ancak tikel ve gerçek varlıklara uygulanabilir. Dolayısıyla her hâl, beraberinde tikel ve gerçek bir zü'l-hâli gerekli kılar. Oysa Ebû Hâşim için bu aksiyom daha esnektir ve hâller sadece gerçek varliğa endeksli değildir. Başka bir ifadeyle zü'l-hâller daha var olmadan önce varlık sıfatını taşıyacak sübuta sahiptir. Nitekim Mu'tezile cenahının baskın çoğunluğuna göre varlık (vücûd) bir sıfat sayılır. ${ }^{30}$ Varlığın sıfat sayılmasını ve nefsî sıfatların, yani illetsiz hâllerin varlık öncesindeki sabitlere (zât ve şeylere) uygulanıyor oluşunu şöyle örnekleyebiliriz: a-cevheri ile kırmızı-1 arazı daha var olmadan önce bir nitelik sayılan varlık sıfatını taşıma potansiyelindedir. Ancak bunlar söz konusu niteliğe sahip olmadan önce de birbirinden ayrı şekilde idrake konu olabilmektedir. Peki a-cevherinin cevher ve kırmızı-1'in de kırmızı şeklinde idrake konu oluşunu sağlayan şey nedir? Bu sorunun yanıtı Mu'tezilî gelenekteki hâl savunucularına göre illetsiz hâldir (ehassü'l-evsâf). Dolayısıyla bu aksiyom Mu'tezile cenahı için varlık öncesi eşikte başlar.

dolayı şekillendiğine dikkat çeker; bkz. Frank, Beings and Their Attributes, 38. Bununla beraber Jan Thiele, başta zât sıfatı (nefs sıfatı) olmak üzere bu konuda Ebû Hâşim'in takipçilerin belli bir standartı yakalayamadığını belirtir; bkz. Thiele, "Abū Hāshim al-Jubbā'ì's”, 371.

29 Muktarah, Şerhu'l-İrşâd, I, 234.

30 Mu'tezile ekolünde bu konu etrafındaki görüş ayrılıkları için bkz. İbnü'l-Melâhimî, el-Fâ' ik fî usûli'd-dîn, thk. Faysal Büdeyr Han (Kahire: Dâru'l-kütüb ve'l-vesâiki'l-kavmiyye, 2010), 82, 133. 
Aksiyom-3 gereği hâller ancak önerme merkezli ele alınabilir. Çünkü hâller sıfattır ve sıfatlar da nitelediği zâtlar tasavvur edilmeksizin düşünülemez. ${ }^{31}$ Bu bağlamda felsefî düşünce sisteminin aksine kelâmî düşüncede bilgiler kavramlar (tasavvurât) ve önermeler (tasdîkât) şeklinde bir taksime tabi tutulmaz. Önerme merkezli düşünce biçimi Cüveynî ve öncesi kelâm literatüründe oldukça ön plandadır. Öyle ki, kelâm atomculuğunun dinamikleri gözetilerek tasarlanan hâllerin bile kavramsal düşünme biçiminin önünü açtığ1 söylenemez. Bu bağlamda söz konusu teorinin örnekleri sürekli "kevnuhû kezâ kezâ" (onun şöyle şöyle oluşu) formatında zikredilir. ${ }^{32}$ Kısacası bu aksiyom, kelâm atomculuğunun tümel modeli olan hâlleri önermelerin yüklemleriyle sınırlamıştır.

Aksiyom-4: Hâllere hâller uygulanamaz. ${ }^{33} \mathrm{Bu}$ aksiyom kelâm atomculuğunun tümel modeli olan hâller teorisini klasik felsefenin tümel modelinden net bir şekilde ayırmaktadır. Nitekim Aristotelesçi tümel modelinin öne çıkan yönü, mecazî anlatının ötesinde hakikî anlamda tümellere tümellerin yüklem olabilmesidir. Bu düşünce yapisında soyut olan bir tümelin yine soyut olan başka bir tümele uygulanması, soyut varlıkların savunulmasının önünü açmıştır. Bu kabule dair Aristoteles'ten şunlar aktarılabilir:

(...) tür şahsa, cins türe ve her ikisi de şahsa yüklem olur. ${ }^{34}$

[Tümel olan] insan herhangi bir insana yüklem olabilir. Canlı da [tümel olan] insana yüklem olabilir. Dolayısıyla zorunlu olarak canlı [tikel olan] insana da yüklem olur. Çünkü [tikel olan] insan hem insan hem de canlıdır. ${ }^{35}$

Yukarıdaki kesit ve pasajda açık bir şekilde hâller teorisini benimseyen kelâmc1ların aksiyom-4'ünün klasik felsefe tarafından benimsenmediğinin açık bir ifadesidir. Aristotelesçilikte gerçek anlamıyla insan tümeline başka bir tümel yüklem olabilir. ${ }^{36}$ Oysa kelâm atomculuğunun tümelleri olan hâller, sadece önermelerde yüklem konumunda kabul edilir. Bu önermelerin özneleri de ancak tikellerden oluşabilir. Bu bağlamda şöyle bir genellemede bulunabiliriz: Aristotelesçilikte tümeller hem

31 Richard M. Frank aksiyom-3’e hâllerin cevher araz gibi bağımsız bir ontolojik gerçekliğe sahip olmadığı şeklinde işaret eder; Frank, "Abū Hāshim's Theory of the 'States”, 92-93. Orhan Şener Koloğlu ise hâllerin bu yönünü “teorinin kilit noktası” şeklinde niteler. Bkz. Orhan Şener Koloğlu, "Ebû Hâşim el-Cübbâînin Ahvâl Teorisi Üzerine Bazı Mülahazalar”, Uludağ İlahiyat Fakültesi Dergisi 16/2 (2007): 208.

32 Bu tür örnekler için bkz. Cüveynî, eş-Şâmil (Neşşâr vd.), 630 vd.

33 Cüveynî, eş-Şâmil (Neşşâr vd.), 698

34 Aristûtâlîs, "Kitâbu'l-Makûlât", en-Nassu'l-kâmil li-mantıkAristû, çev. Ebû Bişr Mettâ b. Yûnus el-Kunnâî, thk. Ferîd Cebr, I (Beyrut: Dâru'l-fikri'l-Lübnânî 1999), 44 (3a: 30).

35 Aristûtâlîs, Kitâbu'l-Makûlât, I, 36 (1b: 10).

36 Aristotelesçilikte tümellerin indirgenme (tevil) gerekesimi hissedilmeden gerçek anlamda önermelerin konusu sayıldığı ilmî sahanın genel kabulüdür. Yine de tümellerin birbiriyle olan ilişkisi etrafında Aristoteles şarihleri arasında cereyan eden tartışmalar ve görüş ayrılıkları konumuzun dışında olduğunu belirtmeliyiz. Bu tartışmalar ve derin analizler için bkz. İbrahim Halil Üçer, İbn Sînâ Felsefesinde Suret, Cevher ve Varlık (İstanbul: Klasik 2017), 123 vd. 
tikellere hem de tümellere, hâller ise sadece tikellere yüklenir. Bu iki ekol arasındaki temel farklılık, kavramlara bakışı da şekillendirmiştir. Nitekim klasik felsefenin söz konusu yüklem anlayışı kavram derinliğine (içlem/mefhum), kavramlar arası dört ilişkiye (en-nisebü'l-erbaa), beş tümel anlayışına (el-külliyâtü'l-hams) ${ }^{37}$ ve kategorik düşünce tarzına zemin oluşturmuştur. Ne var ki bu olgu, aksiyom-4 nedeniyle kelâm atomculuğunun tümel modeli olan hâllerde geçerlilik kazanmamıştır.

Aksiyom-5: Hâller varlık üstüdür. Ontolojiye dair kadim ve hâdis farkı gözetilmeksizin hâller, Eş‘arîlerde sadece varlığı Mu'tezile'de ise hem varlığı hem de varlık öncesi sabit şeyleri kuşatır şekilde tasarlanmıştır. Hâllere bu türden bir aksiyomun atfı, temelde, "Tanrı hakkında konuşabilme imkânı" sağlamayı amaçlar. Nitekim "a-cevheri âlimdir" ile "Tanrı âlimdir" önermelerinde yer alan yüklemler "bir"dir. Bu birliğe zemin sağlayan şey, hâllere atfedilen aksiyom-5'tir. Şayet her iki önermenin yüklemi pozisyonundaki "âlim olma” terimi, "bir” olan sabiti göstermiyorsa, bunların simgelediği bilgiler anlam belirsizliğine yol açar. Çünkü “a-cevheri âlimdir” önermesi “a-cevheri X'tir”, “Tanrı âlimdir” önermesi ise "Tanrı Y'dir” formlarına dönüşür. Bu da, esasında, Tanrı'ya uygulanan “âlim” sıfatından neyin kastedildiğini belirsiz kılar. Cüveynî̀nin öğrencisi Kiyâ el-Herrâsî bu durumu şöyle özetler:

Bunlar [hâlleri kastediyor] tümel önermelerdir ve bunları ancak icmalen bilebilirsin. Zihninde (fîfehmike) âlim olmanın ilimden kaynaklandığı, kadim varlığın âlim olduğu ve O'nun da ilminin var olduğu sabittir. Dolayısıyla burada gâib ve şâhid ayrımı yoktur. Aksine senin gâibin şâhidindir ve şâhidin de gâibindir. İşte yakîn olan budur. Bunu bir örneğe dönüştürelim. Bunun örneği şöyle söylemendir: Bütün A'ların B ve bütün B'lerin de C olduğu bana sabit olursa, bütün A'ların C olduğu da sabit olur. ${ }^{38}$

Bu aksiyom gereği hâller yaratma kapsamının dışında kalır. Kelâmcıların teknik tabiriyle söyleyecek olursak hâller mec'ûl değildir. ${ }^{39}$

Abdülkâhir Bağdâdî, Ebû Hâşim adına üç çeşit hâlden bahseder; Abdülkâhir Bağdâdî, el-Fark beyne’l-firakve beyânü'l-firkati’n-nâciye minhum (Beyrut: Dâru'l-âfâki'l-cedîde 1977), 183). Harry Wolfson da zâtları hesaba katarak Bağdâdî’nin bu taksimi üzerinden Porfiryus'un (ö. 304) beş tümelinin dördüne ulaşılabileceğini savunur (Wolfson, The Philosophy of the Kalam, 188). Ancak aksiyom-4 göz önünde bulundurulduğunda böyle bir sonuca varmak oldukça güçtür. Nitekim dönemin kelâmcıları için tümel konulara yer yoktur. Ayrıca dönemin kelâmcıları tarafından beş tümelden cinsi çağrıștıran "sıfatü'l-ecnâs" tabiri kullanılmış olsa da, onlar bu tabirle klasik felsefedeki cinsi kastetmemişlerdir (Frank, Beings and Their Attributes, 72-73). Şunu da belirtmede yarar var ki, gündelik dilde bile kavramlar arasında dört ilişki kurularak iletişim sağlanır. Dolayısıyla dönemin kelâmcılarının kavramlar arasında ilişki kurmadıkları söylenemez. Asıl vurgulanmak istenen husus, eğer hâller kelâm atomculuğunun tümel modeli ise aksiyom-4 hâllerin ilişki ağını ortadan kaldırdığıdır.

38 Kiyâ el-Herrâsî, Usûlü'd-dîn, 22b.

39 Mu'tezile kelâm geleneğinde hem hâller hem de varlık öncesi zü’l-hâller (şeyler) mec'ûl kabul edilmez. Eş'arî kelâm geleneğinde ise hâllerin mec'ûliyeti hususunda gelgit yaşanmıştır. Daha geniş bilgi için bkz. Mehmet Aktaş, “Cüveynîde Tanım Teorisi” (Doktora tezi, Marmara Üniversitesi, 2020), 143-51. 


\section{Hâllerin Kapsamı}

Hâller teorisi felsefî tümel modelinden "şekil" yönüyle ayrıştığı gibi, kapsam yönüyle de ayrışır. Klasik felsefede "Zeyd insandır” önermesinde yer alan yüklem, bir tümeldir ve bu tümel Zeyd, Amr ve Hind gibi kişi/nesnelere uygulanabilir. Dolayısıyla felsefî tümellerin ana muhatabı, cisimler/nesneler âlemidir. Bu noktayı esas alarak kelâm atomculuğunun tümel modeli olan hâllerin kapsam alanının sorgulanması gerekir. Bu bakımdan "a-cevheri yer kaplayandır" ile "a-cevheri kırmızıdır" önermelerinde yer alan yüklemlerin birer hâl oluşu gibi acaba "Zeyd insandır" veya "Bu hurma ağacı palmiyedir" önermelerindeki yüklemlerin de kelâmî bakışla birer hâle karşıllık gelip gelmediği sorgulanmaya ihtiyaç duyar. Hâller konusuna bu soruşturma çerçevesiyle yaklaşıldığında, Eş'arîlerden hâl savunucularına göre, hâdis âlemde kelâmî tümellerin cisimlerin/nesnelerin yapıtaşı olan cevher-arazlarla sınırl olduğu fark edilir. Dolayısıyla hâllerin "şekil" noktasındaki farklılığı gibi, kapsamının da felsefî tümellerden farklılaştığı rahatlıkla söylenebilir. Bu bakış açısını açıklığa kavuşturmak için iki anahtar terimi tahlil etmek gerekmektedir. Bunlar kelâm literatüründe sıkça yer alan hakikatlerin tersyüz edilmesi (kalbü'l-hakâ'ik) ve telif terimleridir.

Özcü bakış açısına benzer şekilde kelâmcılar da hakikatlerin tersyüz edilemeyeceği noktasında hemfikirdir. Onlar hakikatlerin bu yönünü kalbü'l-hakâ'ik muhâlün şeklinde ifade ederler. Bu minvalde bir cevher, sahip olduğu nefsî sıfattan ayrılamaz, dolayısıyla da kendi tanımının dışına çıkıp başka bir şeye dönüşemez. Mesela cevherler için "cevher olma", "yer kaplama" ve "parçalanamama" nefsî sifatlardandır ve ortak hakikatler mesabesindedir. Dolayısıyla a-cevherinin "cevher olma" hakikatinden ayrılıp "araz olma" hâline sahip olması, hakikatlerin dönüşmemesi ilkesince imkân dışıdır. Bu durum aynı şekilde arazlar için de geçerlidir. Çünkü kırmızı-1 arazı "kırmız olma", "renk olma" ve "araz olma" nefsî sıfatlarına sahiptir. Onun kırmızıdan yeşile, renkten kokuya ve arazdan cevhere dönüşmesi hakikatlerin tersyüz edilmesi anlamına geldiğinden imkânsız addedilir. ${ }^{40}$ Hâdis âlemde nesnelerin yapıtaşıyla ilgili durum böyleyken, nesnelerdeki durum ise aksine seyreder. Nitekim kelâmcılar, bir cevherin araza ve belirli bir arazın da başka bir araz türüne dönüşmesini imkânsız görürlerken; birer nesne olan asa ile yılanın birbirine dönüşmesini aklî imkân içerisinde değerlendirirler. Kelâmcıların bu bakış açısı nefsî sıfatların ancak nesnelerin yapıtaşıyla sınırlı olduğu şeklinde açıklanabilir. Birçok kelâm eserinde rastlandığı gibi, Cüveynî de bu konuya işarette bulunarak şu ifadeleri kullanır: 
Eğer “Cevher için imkânsız olan nedir?" diye sorulursa, deriz ki: Onun nefsî sıfatının dışına çıkması imkânsızdır. Çünkü bu durumda cinsin inkılâbı meydana gelir. ${ }^{41}$

Yukarıdaki parçadan ve benzerlerinden anlaşıldığı kadarıyla bir cevherin başka bir cevhere veya herhangi bir araza dönüşmesi gerçek anlamıyla imkânsızdır (aklî muhâl). Çünkü bu cevher nefsî sıfatlara sahiptir. Onun nefsî sıfatlarının dışına çıması ve gerçek tanımına aykırı düşmesi kelâmcıların tasarladığı hakikat algısına ters düşer. Aynı şekilde kırmızı-1 arazının cevhere veya koku arazına dönüşmesi de bu imkânsızlık çerçevesinde değerlendirilir. Nesnelerin yapıtaşına atfedilen bu durum, mucize gibi birtakım teolojik açıklamalar için nesnelerin bütünü açısından göz ardı edilir. Bu nedenle cevher-araz yığınlarıyla inşa edilmiş nesneler düzeyinde gerçek anlamlıyla, yani değişmezlik ve dönüşmezlik manasında bir hakikat algısı söz konusu değildir. Dolayısıyla bir asanın yılana ve yılanın da tekrardan asaya dönüşümü âdeten, yani normal şartlarda imkânsız addedilse de, kelâm atomculuğunun dayandığı hakikat anlayışıyla çelişmez, bilakis onunla uyumludur. Cüveynîden aktaracağımız aşağıdaki pasaj ve onun benzerleri bu çerçevede değerlendirilmelidir:

Vadilerde taze kanın akması ve dağların som altına dönüşmesi mümkünlerdendir. Ancak akıl sahibi birinin yaşadığı zaman içerisinde böyle bir şeyin mümkün olduğunu ifade etmesi, aklî dengesinin yerinde olmadığı anlamına gelir. ${ }^{42}$

Nefsî sıfatların nesneleri kapsamadığına dair bir diğer anahtar terim ise teliftir. Aksiyom-3 gereği Eş'arîler için hâller sadece varlıkları kapsar. Başka bir ifadeyle ancak tikel ve gerçek mevcutlar, ortak hakikate sahip olabilir. Bu bağlamda var olmayanların ( $m a$ 'dûmât) hakikatinden söz edilemez. Yukarıda açıç̧a ifade edildiği üzere a-cevheri ile b-cevherinin "cevher olma" adında ortak hakikati bulunur. Keza siyah-1 ile siyah-2 arazlarının da "siyah olma" adında ortak hakikatinin sübutundan bahsedilebilir. Ancak "a-cevheri ile b-cevherinin belirli oranlarda yan yana getirilip birbirine temasları sağlandığında ortaya yeni bir hakikat çıkar mı?” sorusunun cevabı, nesneler düzeyinde nefsî sıfatlar, illetsiz hâller ve hakikatlerin olup olmadığ1 hakkında fikir verebilir.

Eş'arîlerin cevher-araz teorisine göre her araz sadece bir cevher tarafından taşınabilir. Bu kabul gereğince a- ile b-cevherlerinin ortaklaşa paylaştıkları bir araz kabul edilmediğinden, cevherler arasında somut bağ görevi görecek "telif" adında bir araz türüne de yer verilmez. ${ }^{43}$ Dolayısıyla eğer telif adında bir araz var değilse onun 
hakikati de sabit olamaz. Başka bir deyişle, var oldukları için a-cevheri ile kırmızı-1 arazının nefsi sıfatları sabittir ama "telif-1" adını verebileceğimiz herhangi bir arazın hakikati sabit değildir. Telif, araz kabul edilmediğinden "a-cevheri ile b-cevheri müelleftir” önermesinde yer alan yüklem, Eş'arîler için herhangi bir hâli göstermez. Oysa "a-cevheri kırmızıdır" önermesinin açıklayıcısı "a-cevheri kırmızı-1 arazını taşıdığından dolayı kırmızıdır" şeklindedir ve yüklem, illetli bir hâli göstermektedir. Ne var ki, "a-cevheri ile b-cevheri müelleftir” önermesinin açıklayıcısı "a-cevheri ile b-cevheri telif-1 arazını paylaştıklarından dolayı müelleftir” şeklindeki bir açıklama Eş'arî hâl savunucularına göre geçerli değildir. Bu bilgiler ışığında bir araz olarak "telif" ve illetli bir hâl olarak "müellef" terimleri, lafzın ötesinde bir değere sahip olamaz. Dolayısıyla iki cevherden oluşan en küçük hacimli bir yapıya atfedilemeyen hakikat, insan ve palmiye gibi cisimlere neden atfedilsin ki? Bu açıklamalar ışığında Cüveynînin öğrencilerinden Ebü'l-Kâsım el-Ensârîye ait aşağıdaki pasaj hakikatlerin cevher ve arazlarla sınırlı kabul edilmesi açısından oldukça çarpıcıdır:

Eğer "Size göre insanın tanımı nedir?" diye sorulursa, deriz ki: Bu bünye ve şekle (sûret) sahip olanlar insandır. Bütün dilciler ve sözlükçüler de bu görüştedir. Kur’an da böyle buyurmuştur. İlim ehli ve Arap sözleri de görünen cesedin insan olduğuna dair görüş birliğindedir. İnsandan kastedilen yaygın şekilde budur (...). [Dilcilerin] at, ev ve palmiye [sözcükleri] ile kastettikleri bu at, bu palmiye ve bu mescit mesabesindeki bilgidir. Eğer biri çıkar da insanın bu bünye olmadığı iddiasında bulunursa, işaret ettiği her bir şeye de aynısını söylemelidir. Kesin şekilde dilcilerin at, ev ve palmiye sözcükleriyle [görünen] atı ve evi kastettiklerini bildiğimiz gibi; insan sözcüğüyle de görünen cesedi kastettiklerini biliyoruz. ${ }^{44}$

Hâlleri savunan Eş'arîler için "cevherin hakikati”, "arazların hakikati” ve "cismin hakikati" tamlamalarında yer alan "hakikat" ifadeleriyle aynı anlam derinliğinin kastedilmediği açıktır. Nitekim ilk iki tamlamada yer alan "hakikat" teriminden nefsî sıfatlar olan illetsiz hâller kastedilirken, "cismin hakikati" tamlamasındaki "hakikat" teriminden ise "a-cevherinin b-cevherine belirli bir orandaki teması" kastedilir. Bu yakınlaşma ve teması Eş'arî kelâmcılar "telif” şeklinde adlandırır ve söz konusu adın gösterdiği şeyin cevher-araz yı̆̆ını olduğunu belirtir. Örneğin Zeyd ile Amr'ın omuz

kabul etmemektedir. Bkz. Ebû Reşîd en-Nîsâbûrî, el-Mesâ'il fi'l-hilâf beyne'l-Basriyyîn ve'l-Bağdâdiyyîn, thk. Ma'n Ziyâde ve Rıdvân es-Seyyid (Beyrut : Ma'hedü’l-İnmâi'l-Arabî, 1979), 219.

44 Ensârî, Şerhu'l-İrşâd, II, Süleymaniye Kütüphanesi, Laleli 2247, 95b-96a. Benzer ifadeler için bkz. İbn Fûrek, Mücerred, 308. Richard M. Frank sadece cevher ile arazların nefsî sıfatlara sahip olduğuna, cisimlerin ise bunların bir bütününden ibaret kaldığına, dolayısıyla cisimlerin ötesinde ruh/nefis gibi birleştirici bir unsurun olmadığına dikkat çeker (Richard M. Frank, "Abū Hāshim's Theory of the 'States"', 90). Bu görüşün arka planına paralel olarak mütekaddimîn kelâmcılar bağlamında insan antropolojisini detaylı bir şekilde inceleyen Ayman Shihadeh, "insan" terimin teolojik anlamının dilsel yapının ötesine geçmediğini savunur. Bkz. Ayman Shihadeh, "Classical Ash'arī Anthropology: Body, Life and Spirit”, The Muslim World 102 (2012): 441. 
omuza yürümesine nasıl "omuz omuza” tabiri kullanılıyorsa, aynı şekilde a-cevheri ile b-cevherinin temasına da "telif/müellef olma/cisim" ifadesi kullanılır. Bu bağlamda "omuz omuza olmak" ortak bir hakikati doğurmadığı gibi, aynı şekilde telif/müellef olma da herhangi bir hakikati ortaya çıkarmaz. Dolayısıyla "a-cevheri bölünemezdir" ile "kırmızı-1 renktir" önermelerinde yer alan yüklemler, konuları için nefsî sıfat, illetsiz hâl, gerçek tanım ve hakikattir. Söz konusu hakikat, dilin ötesinde bir sübuta sahiptir. Oysa yukarıdaki pasajdan açık bir şekilde cisimlere/nesnelere dil ekseninin dışında herhangi ortak hakikatin atfedilmediği anlaşılır. Dolayısıyla dönemin Eş'arîleri tarafından "cevher olma" ile "palmiye olma" terimlerinin aynı kefeye konulup değerlendirilmemesi gerekir.

Hâller teorisini savunan Eş'arî kelâmcılarına göre cevher-araz yığınından müteşekkil herhangi bir nesne, nesne olarak özellik/nitelik taşıyıcısı sayılmaz. İster hayat arazına sahip olsun ister olmasın nesnelere dair kurulan önermeler mecazî anlatıya sahiptir. Bu tür önermeler ancak cevher-araz formatına indirgenerek mecazdan kurtulabilir. Yine Ensârî̀den örnek bir pasaj aktaralım:

[Mu'tezile ile] aramızdaki görüş ayrılığı hükümler bağlamındadır. Bizdeki hükümler dilde geniş kullanım (tevessu) ve mecaz şeklinde bütüne dayanır. Onlar ise mecaz olmaksızın [hükümleri bünyeye] dayandırır. ${ }^{45}$

Kelâmcılar tarafından tikel ve gerçek varlıkların ortak yüklemleri tarzında düşünülen hâller, ayrıca hükümler olarak da tabir edilir. Hükümler daha çok illetli hâller örneklerinde kullanılır. Şöyle ki, ilim-1 arazını a-cevheri gibi sadece bir cevher taşıyabilir. İlim-1 arazını hangi cevher taşıyorsa bu taşıma sonucu ortaya çıkan hâle ve sıfata da o sahiptir. Dolayısıyla a-cevheri ilim-1 arazını taşıyorsa "a-cevheri âlimdir" hükmünde bulunulur. Bu, indirgenmeye (tevil) ihtiyacı olmayan gerçek bir önermedir. Oysa "Zeyd âlimdir” önermesinin durumu farklıdır. Çünkü bir cisim olarak Zeyd devasa çokluktaki cevherlerin belirli oranlarda yan yana gelmesinden ibarettir. Dönemin Eş'arîlerine göre ilim-1 arazı Zeyd'in bünyesi tarafından taşınamaz. Çünkü her bir araz ancak bir cevher tarafından taşınır. Bu doğrultuda ilim-1 arazı Zeyd'in bünyesinde yer alan cevherlerden örneğin sadece a-cevheri tarafından taşınır. Dolayısıyla “âlim” hükmünü hak eden Zeyd'in bünyesi değil, bünyede yer alan a-cevheridir. ${ }^{46} \mathrm{Bu}$ bağlamda "Zeyd'in bünyesinde yer alan a-cevheri ilim-1 arazını taşıdığından dolayı sadece o cevher âlimdir" önermesi "Zeyd âlimdir" önermesinin indirgenmiş şeklidir. Bu bakış açısı da gösteriyor ki, dönemin Eş'arî kelâmcılarının

46 Richard M. Frank, "Bodies and Atoms: The Ash'arite Analysis", Classical Islamic Theology: The Ash'arites Texts and Studies on the Development and History of Kaläm III, Richard M. Frank, ed. Dimitri Gutas (Hampshire: Ashgate Variorum, 2008), 289. 
nesnelere dair inşa ettikleri önermeler cevher-araz katmanına indirgenmeden mecazî anlatıdan kurtulamaz. ${ }^{47}$ Dolayısıyla "âlim olma” gibi bir yüklemin konusu ve muhatabı klasik felsefede mahiyetler veya cisimler iken, Eş‘arî kelâmında cisimlerin yapıtaşlarıdır. Böylece Eş‘arî gelenek içerisinde hâlleri savunanların nesneler düzeyinde adcı (nominalist), nesnelerin yapıtaşı olan cevher-araz katmanında ise özcü (realist) reflekslere sahip olduğu sonucuna varılabilir. Gerçekliğin keskin çizgilerle hâdis âlemde nesneler ile onların yapıtaşları şeklinde ikiye ayrılması ve bunlardan sadece yapıtaşlarına nefsî sıfatların uygulanması, dönemin Eş‘arî âlimlerini yarı/ kısmî özcü pozisyona getirdiği söylenebilir. Her ne kadar "yarı/kısmî özcülük” tabiri düşünce tarihinde yer almasa da, kelâm atomculuğunun tümeller modeli olan hâllere "kapsam" yönüyle bu şekilde bir kavramlaştırmada bulunulabileceği kanaatindeyiz.

\section{Hâllerin Yeri}

Gazzâlî ve sonrası eserlerde bazen açık bazen de dolaylı şekilde hâllerin tümellere (külliyyât) karşılık geldiği ifade edilir. ${ }^{48}$ Ortak payda dikkate alınarak varlığı kuşatacak şekilde tasarlanmaları, hâllerin tümeller kategorisinde değerlendirilmesinin başat nedeni olarak gösterilebilir. Fakat hâller şekil ve kapsam açısından bu modellerden ayrıştığı gibi, "yer” noktasında da onlardan farklılık gösterir. Önce felsefî tümellerin “yer” noktasında nasıl modellendiğini Porfiryus'un meşhur eseri Îsâgûcîde yer alan giriş pasajıyla sıralayalım. Ardından da hâllerin "yer"i hususuna değinelim:

Öncelikle cinsler ve türlerin varlıklarının zihnin ötesinde ('ayân) veya zihindeki soyut düşünceler şeklinde var olup olmadığı; eğer varlıkları zihnin ötesinde ise bunun cisim olup olmadığı; sonra bunların duyumsanan nesneden bağımsız olup olmadığı veya ondan oluşup oluşmadığı gibi hususları ele almayacağım. Bu, geniş bir izaha ihtiyaç duyan çetin bir konudur. ${ }^{49}$

47 Mu'tezile-Eş'ariyye ayrımında bulunmadan nefsî sıfatların cevherler ve arazlarla sınırlı olduğunu belirten Richard M. Frank (Richard M. Frank, “Abū Hāshim's Theory of the 'States”', 89-90), hâllere karşıllk gelen hükümlerin ise Eş'arîlerde mecazen cisimlere yüklendiğini kaydeder. Bkz. Richard M. Frank, "Al-Ahkām in Classical Ash'arite Teaching”, 757.

48 Richard M. Frank hâllerin tümellerle bağdaştırılması hususuna temkinli yaklaşır. Ona göre kelâm sisteminin tümeller anlayışıyla bağdaştırılması sistemi temelden sarsmaktadır (bkz. Frank, “Abū Hāshim’s Theory of the 'States'”, 89). Ne var ki Frank, tümeller anlayışının kelâm sistemini ne gibi noktalarda sarstığına dair herhangi bir açıklamada bulunmaz. Eğer hâllerin Platoncu veya Aristotelesçi bir tümel modeli şeklinde yorumlanmasını kastediyorsa kaygılarına hak verilir. Ancak hâllerin kelâm atomculuğuna uyarlanan bir tümel modeli olması mütekaddimîn kelâm anlayışını neden sarsın?

49 Porfiryus, Îsâgûcî, çev. Ebû Osmân ed-Dimaşkî, thk. Ahmed Fuâd el-Ahvânî (Kahire: Dâru ihyâi'l-kütübi'l-Arabiyye 1952), 67; Porphyry, "Isagoge", Five Texts on the Medieval problem of Universals: Porphyry, Boethius, Abelard, Duns Scotus, Ockham, çev. ve ed. Paul Vincent Spade (Indianapolis: Hackett Publishing Company 1994), 1. 
Yukarıdaki pasaj esas alındığında "Zeyd insandır" önermesini oluşturan "insan" yüklemi bir tümeli gösterir. Kendisine varlık atfedilen bu tümelin "yer"i neresidir? Bu sorunun muhtemel cevapları (i) zihinde, (ii) zihnin ötesinde olup Zeyd'i aşkın, (iii) zihnin ötesinde olup Zeyd'e içkin ve -pasajda yer almamakla beraber- (iv) kelimede olmak üzere kabaca dörde ayrılabilir.

(iv) Hâlleri benimseyenlere göre hâller kesin bir şekilde kelimelerin ötesinde tasarlanmıştır. Çünkü hâlleri reddeden Cüveynî ve öncesi kelâmcılara göre "a-cevheri âlimdir" önermesinin açıklayıcı cümlesi "a-cevheri ilim-1 arazını taşıdığından dolayı âlim adını almıştır" şeklindedir. Bu açıklayıcı cümlede yer alan "âlim adı" ifadesi, dönemin hâl karşıtlarının hem nesne hem de nesnelerin yapıtaşları hakkında inşa ettiği önermelere adcı refleksle yaklaşım gösterdiğinin kanıtıdır. ${ }^{50}$ Ancak hâlleri savunanlara göre söz konusu önermenin açıklayıcı cümlesinde "ad" ifadesi yer almamalıdır. Onlara göre "âlim" terimi sözcüklerin ötesinde sabit kabul edilen hâli gösterir. Nitekim dillerden yoksun şekilde yalnız başına yaşayan ada sakini metaforunu Cüveynî,

(...) çünkü bir adada yalnız yetişen ve kendisine herhangi bir dilin öğretimi ulaşmayan kişinin -dil bilmediği için-sıfatları ispat edecek bir yöntem bulamaması gerekir. Aynı şekilde var olduğu sırada diller yok olur veya değişip dönüşürse, bu doğrultuda hakikatlerin de yok olması veya değişip dönüşmesi gerekir ki, bu da fark edilmesi hiç de güç olmayan büyük bir cehalettir. ${ }^{51}$

şeklinde ifade ederek hakikatlerin ne ölçüde sözcüklerin ötesinde olduğuna dair inancını belirtir. Dolayısıyla hâller teorisi herhangi bir şekilde adcı kuramlarla bağdaştırılamaz.

(iii) Ilımlı gerçekçilik şeklinde bilinen Aristotelesçi tümel modelinde tümeller nesnelerin "içinde" kabul edilir. Bu modele göre "Zeyd insandır" önermesinin öznesini oluşturan Zeyd, somut nesnesi varlık ile insan öz/mahiyetinin birleşiminden ibarettir. Bir başka ifadeyle "insan” tümeli, Zeyd nesnesinin esas birleşenlerindendir. Ne var ki ahvâl teorisindeki esas kategori, tikel varlıklardır ve hâller ile hakikatler bu kategoriye ancak sıfat olma bakımından bağlıdır.

(ii) Katı gerçekçilik şeklinde bilinen Platoncu idealar/tümel modelinde ise esas kategori idealardır. İdealar hem gerçek varlıktır hem de gölge sayılan tikel varlıkların ilkesidir. Platon bu tümel modelini şöyle özetler:

Hiç doğmadığı halde her zaman var olan nedir? Hep geliştiği halde hiç var olmayan nedir? Birincisi düşünüşün yardımıyla akıl tarafından sezilir. Çünkü her zaman aynıdır; 
ikincisine gelince onu kanaatle akla dayanmayan duyum tasarlar, çünkü o doğar ve ölür; ama hiçbir zaman var değildir. ${ }^{52}$

Evet, hâller de yaratma kapsamında değildir (gayr mec $\hat{u} l$ ) ve tikellerin buluştuğu ortak hakikatleri temsil eder. Ancak idealar tikel varlıkların ilkesi şeklinde tasarlanmış iken, hâller sıfat olduklarından sürekli zü'l-hâllerine tabidir. Başka bir ifadeyle tikel varlıklar hâllerin ilkesidir. Nitekim "a-cevheri âlimdir" önermesinin açıklayıcısı, "a-cevheri ilim-1 arazını taşıdığından dolayı âlim hâlini almıştır” şeklindedir. Bu açıklayıcı cümlede "âlim" hâlinin nedeni ve ilkesi ilim-1 arazıdır.

(i) Cüveynînin ömrünün sonlarına doğru kaleme aldığı el-Burhân fî usûli'l-fikıh ile başlayan ${ }^{53}$ ve Gazzâlînnin telif ettiği eserlerle zirveye çıkan Aristotelesçi tümel modelinin kullanımı, Cüveynînin öğrenci ve şârihleri tarafından hâllerin tümellerle bağdaştırılıp zihne ait varlıklar şeklinde yorumlanmasıyla sonuçlanmıştır. Cüveynî’nin yakın dönemindeki kelâmcılar, tümeller ile hâller kuramlarının aynı şeyin iki farklı ifadesi olduğu kanaatindedir. ${ }^{54}$ Hâllerin zihin ötesinde iken zihne ait kılınması, teorinin ontolojiden kopartılıp epistemoloji ekseninde değerlendirilmesine yol açmıştır. Ne var ki, bu teorinin çıkışı ilâhî sıfatların çözümüne dayanır ${ }^{55}$ ve böyle bir yorum ilâhî sıfatların zihnin bir tasarısından ibaret olduğu tehlikesini doğurur. Ayrıca teoriye dair serdedilen örnekler hâllerin zihnî tasarımlar şeklinde yorumlanmasından oldukça uzaktır. Bu bağlamda hâllerin "yeri” ile ilgili en açık ifade Şehristânî tarafından dile getirmiştir:

Hâlleri reddedenler, genel-özel (âm-has) ifadelerini sözcüklere indirgeyerek hata yapmıştır. Ama "a yânda (hariçte) varlığı sabit olan için ne genellik ne de itibar vardır" sözleriyle de doğruyu bulmuşlardır. Hâlleri savunanlar ise genel-özel ifadeleri a'yândaki sıfatlara indirgeyerek hata yapmıştır. Ama "bunlar sözcüklerin ötesindeki aklî anlamlardır" sözleriyle de doğruyu bulmuşlardır. Ancak hâlleri savunanlar "hâller ne vardır ne de yoktur" sözünü "hâller zihinlerde düşünülen varlıklardır" sözüyle değiştirmeliydiler. ${ }^{56}$

52 Platon, Timaios, çev. Erol Güney ve Lütfi Ay (İstanbul: Sosyal Yayınlar, 2001), 23 (28a).

53 Cevher-araz türleriyle sınırlı olan kelâm atomculuğunun tümel modelinden nesne türlerine hitap eden Aristotelesçi tümel modeline geçişin Cüveynînin el-Burhân adlı eseriyle başladığına dair bkz. Aktaş, “Cüveynî̀de Tanım Teorisi”, 257-59.

54 Hâller teorisinin zihne ait tümeller olduğuna dair yorumlar için bkz. Gazzâlî, Tehâfütü’l-felâsife, thk. Selâhaddin el-Hevvârî (Beyrut: el-Mektebetü'l-Asriyye, 2010), 188; Gazzâlî, Mi'yâru'l-ilm fi'l-mantık, thk. Selâhaddin el-Hevvârî (Beyrut: el-Mektebetü'l-Asriyye, 2015), 17; Gazzâlî, Mihakkü'n-nazar fi'l-mantık, thk. Ahmed Ferîd el-Mezîdî (Beyrut: Dâru'l-Kütübi'l-İlmiyye 2003), 213-14; Gazzâlî, el-Mustasfâ min ilmi'l-usûl, thk. Muhammed Tâmir, I (Kahire: Dâru'l-Hadîs 2011), 62-63; İbn Meymûn, Şerhu'l-İrşâd, 199200; İbn Bezîze, el-İs'âd fí şerhi'l-İrşâd, thk. Abdürrezzâk Besrûr ve İmâd es-Süheylî (Kuveyt: Dâru'z-Ziyâ 2014), 199-200.

55 Yavuz, "Ahvâl", 190.

56 Şehristânî, Nihâyetü'l-ikdâm fí ilmi'l-kelâm, thk. Ahmed Ferîd el-Mezîdî (Beyrut: Dâru'l-Kütübi'l-i̇lmiyye, 2004), 144. 
Hâllerin zihne ait varlıklar olması gerektiği konusunda 1srarcı olan Şehristânî pasajdaki "Hâlleri savunanlar ise genel-özel ifadeleri a'yândaki (zihin dışındaki) sıfatlara indirgeyerek hata yapmıştır" vurgusuyla hâl savunucularına göre hâllerin zihinde yer alan durumlar olmadığının altını çizer. ${ }^{57}$ Bu bağlamda hâllerin "ne vardır ne de yoktur" şeklinde tanıtılması, dönemin kelâmcılarının varlık anlayışlarının dayandığı cevher-araz teorisi merkezinde yorumlanmaya ve değerlendirilmeye ihtiyaç duyar. Nitekim Kiyâ el-Herrâsînin Bâkıllânî'den alıntısı bu yorum ve değerlendirme için fikir vericidir:

Kâdî [Bâkıllânî] şöyle dedi: Hâllerin mevcut olmadığını söylüyorum. Çünkü seleflerimin (şuyûhî) uzlaştığı bir ıstılah söz konusudur. O da onların: "Allah dışındaki her şey ya cevher ya da arazdır" sözleridir. Dolaysıyla sen gerçeğin farkına vardıktan sonra, hâller için hangi ifadeyi kullanmak istersen kullanırsın. Bunlar ayrım sağlayanlar derecesindedir ve bilinen sabitlerdir. Hâllere ne mevcûd ne de ma'dûm ifadesini kullanırız. ${ }^{58}$

Bu pasaj Şehristânî'den alıntılanan pasajla beraber değerlendirildiğinde "hâller" adı altında kelâm atomculuğunun tümel modelini savunan kelâmcıların yerleşik olan cevher-araz kavram çerçevesinin dışına çıkmak istemedikleri fark edilir. Bu bağlamda "Hâdis âlemde var olanlar nelerdir?" sorusuna verilen yegâne yanıt "cevherler ve arazlar" olunca, hâller üçüncü bir varlık çeşidi olarak dönemin literatüründe yerini alamadığını söylemek güç değildir. Dolayısıyla hâllerin "ne vardır ne de yoktur" şeklindeki tanıtımı üçüncü şıkkın imkânsızlığı ilkesine meydan okuma gibi algılanmamalıdır. ${ }^{59}$ Bir bakıma Bâkıllânî’nin ifadelerinden sezilen hâllerin bir varlık çeşidi olduğudur. Ancak bu varlık çeşidinin cevher-araz gibi tikel ve somut bir gerçekliğe sahip olmadığıdır. Varlık eşiğine daha yakın durması ${ }^{60}$ ve tanıtım yö-

Louis Gardet bu teoriyi kavramcı anlayışın bir türü (sort of conceptualism) şeklinde yorumlar; Louis Gardet, "Al-Djubbā’ì", EI², II, 570. Ancak Frank, böyle bir yorumun hatalı olduğuna inanır (Frank, "Abū Hāshim's Theory of the 'States”, 85). Bununla beraber birçok modern çalışmada da hâllerin müteahhirîn metinlerindeki "zihnî varlık" yorumuna sıcak bakılmaz. Örnek olarak bkz. Robert Wisnovsky, "Essence and Existence in the Eleventh- and Twelfth-Century Islamic East (Mašriq): A Sketch", The Arabic, Hebrew and Latin Reception of Avicenna's Metaphysics, ed. Dag Nikolaus Hasse ve Amos Bertolacci (Berlin: De Gruyter, 2012), 37; Murat Kaş, "Seyyid Şerîf Cürcânî̀de Zihnî Varlık” (Doktora tezi, Marmara Üniversitesi, 2017), 179; Fedor Benevich, "The Metaphysics of Muhammad b. 'Abd al-Karīm al-Šahrastānī (d. 1153): Ahwāl and Universals", Islamic Philosophy from the $12^{\text {th }}$ to the $14^{\text {th }}$ Century, ed. Abdelkader Al Ghouz (Göttingen: Bonn University Press 2018), 350.

58 Kiyâ el-Herrâsî, Usûlü'd-dîn, 115b.

59 Osman Demir'e göre kelâmcılar, üçüncü şıkkın imkansızlığı ilkesini ihlal amacıyla hâlleri "ne vardır ne de yoktur" şeklinde tanıtmamıştır; bkz. Osman Demir, “Cüveynî̀de Ahvâl Teorisi”, İslam Araştırmaları Dergisi 20 (2008): 74. Ayrıca Cüveynînnin eserleri takip edildiğinde en azında epistemik zeminde bu mantık ilkesinin kesin bir dille savunulduğu fark edilir. Nitekim bu ilkeyi Cüveynî ve leyse beyne'n-nefyi ve'l-isbâti derecetün (olumlu ve olumsuz arası bir durum yoktur) şeklinde ifade eder. Bkz. Cüveynî, eş-Şâmil (Neşşâr vd.), 139, 314, 152, 639; Cüveynî, eş-Şâmil (Frank), 5; Cüveynî, el-İrşâd, 37.

60 Son Mu'tezilî âlimlerinden biri olan ve Fahreddin er-Râzînin Muhassal adlı eserine haşiye yazan İbnü’l-Hadîd (ö. 656/1258) hâlleri varlık dereceleri içerisinde değerlendirir. Bu değerlendirme için bkz. İbnü'l-Hadîd, Tâ'likâ ale’l-Muhassal, İstanbul Üniversitesi Yazma Eserler Kütüphanesi, AY274, 52-53. 
nünün zayıf bulunması nedeniyle hâller modern çalışmalarda birçok farklı terimle tabir edilmiştir. ${ }^{61}$

\section{Sonuç}

Birtakım önermelerin yüklemlerinden ibaret olan hâllerin bağlı olduğu konular "zât" adı altında toplanır. Ancak bu kavram hâlleri savunan Bâkıllânî ve Cüveynî için daha geniş bir kaplama sahiptir. Hâlleri reddeden Eş'arîler nezdinde a-cevheri bir zâttır. Bu zâtın taşıdığı arazlar ise gerçek anlamda sıfattır. Onların bu bakışı kadim varlık alanına da aynı şekilde yansımış ve ilâhî mânâlar gerçek anlamda sıfat kabul edilmiştir. Böylece "Tanrı âlimdir” önermesi birer tikel varlık olan Tanrı'nın zâtı ve O'nun ilim manasından oluşur. Hâlleri reddeden dönemin Eş'arîleri nezdinde soyut referansı çağrıştıran önermenin yüklemi ontik değer barındırmayan lafızlardan ibarettir. Bu bağlamda sadece cevherler ve Zât-i ilâhî zât kategorisinde yer alır. Sifatlar ise arazlar ve ilâhî manalarla sınırlıdır. Oysa Bâkıllânî ve Cüveynîye göre nefsî sıfata (illetsiz hâl) sahip her bir varlık tanım kapsamındadır ve zât kategorisine dâhildir. Böylece cevherler ve Zât-i ilâhî ile beraber tikel gerçekliğe sahip olan arazlar ve ilâhî mânâlar da zât kategorisinde değerlendirilir. Stfat kategorisinde ise sadece hâller yer alır. Dolayısıyla hâl savunucularına göre sıfatlar tikel gerçekliğe sahip değildir.

Tikel varlıklar için ortak sıfat ve hakikatler şeklinde tasarlanan hâllerin lafızlardan ibaret kabul edilmemesi, uygulandığı zâttan başka değerlendirilmesi (zâid) ve soyut referansa sahip olması yönleriyle tümel kategorisine dâhil olur. Ancak tümel sayılmasına rağmen "şekil", "kapsam” ve "yer" bakımından farklı bir tümel modeli görüntüsü çizer. Kelâm atomculuğuyla uyumlu olarak tasarlanan bu tümel modeli, “şekil” yönüyle sadece sıfat, yani yüklem pozisyonunda değer görür. Dolayısıyla hâllerle inşa edilen önermeler, ancak tikel özne ve tümel yüklemden oluşabilir; yani önermelerin konusu zât, yüklemleri ise hâl adıyla tabir edilen sıfatlardan ibarettir.

61 Hâller teorisi Harry A. Wolfson tarafından "modes" tabiriyle ele alınır (Wolfson, The Philosophy of the Kalam, 167 vd.). Richard M. Frank ise erken çalışmalarında durum anlamına gelen "state" ifadesini kullanır. Örnek olarak bkz. Frank, "Abū Hāshim's Theory of the 'States”'; Richard M. Frank, "Al-Ma'dūm wal-Mawjūd: The Non-Existent, the Existent and the Possible in the Teaching of Abū Hāshim and His Followers", Early Islamic Theology: The Mu'tazilites and al-Ash'ari, Texts and Studies on the Development and History of Kalām II, Richard M. Frank, ed. Dimitri Gutas (Surrey: Ashgate Variorum, 2011), 195. Ancak bu ifadenin hâller teorisini tam karşılamadığına dikkat çeken Jan Thiele, Frank'in sonraki çalışmalarında Eş'arîler bazında özellik anlamına gelen "feature" tabirine de yer verdiğini belirtir; bkz. Frank, Beings and Their Attributes, 37; Richard M. Frank, "Al-Ahkām in Classical Ash'arite Teaching", 771; Jan Thiele, "Abū Hāshim al-Jubbā'î's”, 381. Fedor Benevich ise Frank'e atıfla hâllerin herhangi bir kavramla karşılanmamasından yanadır. Ancak bununla birlikte hâllere metafizik gerçeklik (metaphysical reality) tabirinde bulunur. Tümeller sorunu baz alındığında Fedor'un tabiri daha açıklayıcı gibi duruyor; bkz. Benevich, "The Classical Ash'arī Theory of Ahwāl”, 137, 142. 
Bu bağlamda ahvâl teorisi çerçevesinde bir hâl başka bir hâle yüklem olamadığından hâllerin kavram derinliği ve içlem boyutu ortaya çıkmaz. Başka bir deyişle hâller sadece kaplam merkezlidir. Kaplam merkezli olması nedeniyle kavramlar arası ilişki, beş tümel ve kategorik düşünce tarzı, bu sistem içerisinde kendini göstermez. Dolayısıyla dönemin kelâmcılarının kavram anlayışı olan hâllerin içlem boyutu öne çıkmaz. "Şekil” adı altında değerlendirdiğimiz hâllerin bu yönü, onları en genel kavramlar seviyesine taşımıştır. Bu bağlamda hâllere biçilen "şekil” üzerinden kadim varlık ile hâdis varlık arasında bir kavram köprüsü inşa edilmiş olur. Bir bakıma bu yolla "Tanrı âlimdir" ile "a-cevheri âlimdir" yüklemleri ortak bir kümede buluştuğu için Tanrı'ya uygulanan "âlim” yüklemi tanımsız bir yüklem olmaktan çıkar. Ayrıca zâtlara yüklem olan ortak sıfatlar anlamındaki hâller, yüklendiği zâttan başka (zâid) kabul edildiği için önermelerde ortaya çıkabilecek totolojinin önüne geçilir. Aksi takdirde, yani önermenin öznesinin ve yükleminin aynı "şey"i göstermesi durumunda "a-cevheri yer kaplayandır" önermesi "a-cevheri a-cevheridir” formuna dönüşür. Bu önermede yer alan yüklem her bir cevheri ortak bir paydada buluşturduğundan gerçek bir tanım sağlanmış olur. Böylece hâller yoluyla zâtlar arasında aynı olma (mümâselet) ve farklı olma (muhâlefet) sağlanır.

Felsefî tümeller tamamen ve Mu'tezilî gelenekteki hâller ise kısmen nesneler düzeyiyle ilgilidir. Dolayısıyla "Zeyd âlimdir” önermesi herhangi bir değişim ve dönüşüme tabi tutulmadan her iki sistem için mecazî anlatıdan uzak, hakikî bir önerme sayılır. Ne var ki, aynı önerme Cüveynî ve öncesi Eş'arî kelâmcıların bakışında indirgenmeye (tevil) ihtiyaç duyan mecazî bir anlatıya sahiptir (zikrü'l-küll ve irâdetü'l-cüz). Bu önermenin mecazî anlatıdan sıyrılmış şekli "Zeyd'in bünyesinde yer alan a-cevheri ilim-1 arazını taşıdığından dolayı sadece o cevher âlim hâli ile nitelenir" formundadır. Bu bağlamda her ne kadar geniş bir kullanımla Zeyd nesnesine "âlim olma" yükleminde bulunuluyor olsa da, esasında Eş‘arîler açısından gerçek anlamda âlim olan ilim-1 arazını taşıyan a-cevheri gibi bir cevherdir. Dolayısıyla Eş'arîler içerisinde hâlleri savunanlara göre nesneye dair zikredilen yüklemler nesnenin yapıtaşlarından cevher ve arazlara döner. Kelâm atomculuğunun tümel modeli olan hâllerin "kapsam"1 hâdis âlemde cevher-araz katmanıyla sınırlıdır. Bu sınırlama, dönemin Eş‘arî kelâm sistemini yarı/kısmî özcü pozisyonuna getirir.

Hâller teorisini savunan kelâmcıların en önemli iddiası "a-cevheri yer kaplayandır" şeklindeki önermede yer alan yüklemin a-cevherinden başka (zâid) kabul edilişidir. "Yer kaplama" ve benzeri terimlerin lafizdan ibaret kabul edilmemesi, temelde, hâl savunucularını cevher-araz düzeyinde nominalist reflekslerden uzaklaştırarak realist bakış açısına yakınlaştırır. Buna rağmen Bâkıllânî ve Cüveynî’nin hâl kuramı tam anlamıyla herhangi bir realist kuram içerisine yerleşemez. Çünkü esas noktalarda 
aşırı ve 1lımlı realist tümel modellerinden farklılaşan bu teori, conceptualist tümel modeline de uzaktır. Dolayısıyla en azından tetkik edilen metinler bazında hâllerin lafızda, nesnenin "içinde”, bağımsız bir varlık olarak nesneden aşkın ve de zihinde "yer" bulan bir tümel olarak modellemek güçtür. Tüm bu farklarına rağmen kelâm atomculuğuyla uyumlu olacak şekilde teorize edilen hâllerin tümel modellerinden biri olarak değerlendirilmesi gerektiği kanaatindeyiz.

\section{Bibliyografya}

Aktaş, Mehmet, “Cüveynî̀de Tanım Teorisi”, doktora tezi, Marmara Üniversitesi, 2020.

Aristûtâlîs, "Kitâbu'l-Makûlât", en-Nassu'l-kâmil li-mantık Aristû I içinde, çev. Ebû Bişr Mettâ b. Yûnus el-Kunnâî, thk. Ferîd Cebr, Beyrut: Dâru'l-fikri'l-Lübnânî, 1999.

Bağdâdî, Abdülkâhir, el-Fark beyne'l-firakve beyânü'l-fırkati'n-nâciye minhum, Beyrut: Dâru'l-Âfâki'l-cedîde, 1977.

Benevich, Fedor, "The Classical Ash'ari Theory of Ahwāl: Juwaynī and his Opponents", Journal of Islamic Studies 27.2 (2016), 136-175.

, "The Metaphysics of Muhammad b. 'Abd al-Karīm al-Šahrastānī (d. 1153): Ahwāl and Universals", Islamic Philosophy from the $12^{\text {th }}$ to the $14^{\text {th }}$ Century, ed. Abdelkader Al Ghouz, 327-355, Göttingen: Bonn University Press, 2018.

Cüveynî, İmâmü'l-Harameyn, eş-Şâmil fî usûli'd-dîn, thk. Richard M. Frank, Tahran: Müessese-i Mütâlaât-1 İslâmî Dânişgâh-1 McGill Şu'be-i Tehrân, 1981.

-------, eş-Şâmil fî usûli'd-dîn, thk. Ali Sâmî en-Neşşâr, Süheyr Muhammed Muhtâr ve Faysal Bedir Avn, İskenderiye: Münşeâtü'l-Maârif, 1969.

-------, et-Telhîs fí usûli'l-fikh, thk. Muhammed Hasan İsmail, Beyrut: Dâru'l-Kütübi'l-İlmiyye, 2003.

-, Kitâbu'l-İrşâd ilâ kavâtı'i'l-edille fí usûli'l-i'tikâd, thk. Muhammed Yûsuf Mûsâ, Kahire: Mektebetü'l-Hancî, 1950.

Dağ, Mehmet, “İmam el-Haremeyn el-Cüveyni’de Nedensellik Kuramı”, Ondokuz Mayıs Üniversitesi İlâhiyat Fakültesi Dergisi 2 (1987), 35-53.

Demir, Osman, “Cüveynî'de Ahvâl Teorisi”, İslâm Araştırmaları Dergisi 20 (2008), 59-78.

Ebû Reşîd en-Nîsâbûrî, el-Mesâ'il fi'l-hilâfbeyne'l-Basriyyîn ve'l-Bağdâdiyyîn, thk. Ma'n Ziyâde ve Rıdvân es-Seyyid, Beyrut: Ma'hedü'l-İnmâi'l-Arabi, 1979.

Ebü'l-Kâsım el-Ensârî, Şerhu'l-İrşâd, I, Princeton University Library, Garrett Collection of Arabic Manuscripts $634 Y$ Y.

-------, Şerhu'l-İrşâd, II, Süleymaniye Kütüphanesi, Laleli 2247.

el-Eş'arî, Ebü'l-Hasan, Makâlâtü'l-İslâmiyyîn ve ihtilâfü'l-musallîn, thk. Naîm Zerzûr, II, Beyrut: el-Mektebetü’l-Asriyye, 2005.

Frank, Richard M, “Abū Hāshim's Theory of the 'States': İts Structure and Function”, Early Islamic Theology: The Mu'tazilites and al-Ash'arī, Texts and Studies on the Development and History of Kaläm II, Richard M. Frank, ed. Dimitri Gutas, 85-100, Surrey: Ashgate Variorum, 2011. 
, "Al-Ahkām in Classical Ash'arite Teaching", Classical Islamic Theology: The Ash'arites, Texts and Studies on the Development and History of Kaläm III, Richard M. Frank, ed. Dimitri Gutas, 753-77, Hampshire: Ashgate Variorum, 1979.

, "Attribute, Attribution and Being: Three Islamic Views", Classical Islamic Theology: The Ash'arites Texts and Studies on the Development and History of Kalām III, Richard M. Frank, ed. Dimitri Gutas, 258-278, Hampshire: Ashgate Variorum.

, "Bodies and Atoms: The Ash'arite Analysis", Classical Islamic Theology: The Ash'arites Texts and Studies on the Development and History of Kalām III, Richard M. Frank, ed. Dimitri Gutas, Hampshire: Ashgate Variorum.

, “The Ash'arite Ontology: I Primary Entities”, Classical Islamic Theology: The Ash'arites: Texts and Studies on the Development and History of Kalām III, Richard M. Frank, ed. Dimitri Gutas, 163-231, Hampshire: Ashgate Variorum, 2008.

, Beings and Their Attributes: The Teaching of Basrian School of the Mu'tazila in the Classical Period, Albany: State University of New York Press, 1978.

, "Al-Ma'dūm wal-Mawjūd: The Non-Existent, the Existent and the Possible in the Teaching of Abū Hāshim and His Followers", Early Islamic Theology: The Mu'tazilites and al-Ash'arī, Texts and Studies on the Development and History of Kalām II, Richard M. Frank, ed. Dimitri Gutas, Surrey: Ashgate Variorum, 2011.

Gardet, Louis, “Al-Djubbā'î”, EI², II, 569-70.

Gazzâlî, Ebû Hâmid, el-Mustasfâ min ilmi'l-usûl, thk. Muhammed Tâmir, I, Kahire: Dâru'l-Hadîs, 2011.

-------, Mi'yâru'l-'ilm fi'l-mantık, thk. Selâhaddin el-Hevvârî, Beyrut: el-Mektebetü'l-Asriyye, 2015.

-------, Mihakkü'n-nazar fi'l-mantık, thk. Ahmed Ferîd el-Mezîdî, Beyrut: Dâru'l-Kütübi'l-İlmiyye, 2003.

-------, Tehâfütü’l-felâsife, thk. Selâhaddin el-Hevvârî, Beyrut: el-Mektebetü’l-Asriyye, 2010.

Grünberg, Teo ve David Grünberg, Metafizik, ed. İskender Taşdelen, Eskişehir: Anadolu Üniversitesi, 2010.

Güdekli, Hayrettin Nebi, “Ebû Hâşim el-Cübbâînin Zât-Sıfat İlişkisine Yaklaşımı: Haller Teorisi”, yüksek lisans tezi, Marmara Üniversitesi, 2008.

İbn Bezîze, Ebû Fâris et-Tûnisî, el-İs'âd fi şerhi'l-İşâd, thk. Abdürrezzâk Besrûr ve İmâd es-Süheylî, Kuveyt: Dâru'z-Ziyâ, 2014.

İbn Fûrek, Ebû Bekir el-Ensârî, Mücerredü Makâlâti’ş-Şeyh Ebi'l-Hasan el-Eş‘arî, thk. Ahmed İbrahim es-Sâih, Kahire: Mektebetü's-sekâfeti'd-dîniyye, 2005.

İbn Metteveyh, et-Tezkire fi ahkâmi’l-cevâhir ve'l-a'râz, thk. Sâmî Nasr Latif ve Faysal Büdeyr Avn, Kahire: Dâru's-Sekâfe, 1975.

İbn Meymûn, Ebû Bekir, Şerhu'l-İş̧âd, thk. Ahmed Hicâzî ve Ahmed es-Sekkâ, Mısır: Mektebetü'l-Angle el-Misriyye, 1987.

İbnü'l-Emîr, el-Kâmil fî usûli'd-dîn fì ihtisâri'ş-Şâmil fî usûli'd-dîn, thk. Cemâl Abdünnâsır Abdülmün'im, II, Kahire: Dâru's-Selâm, 2010.

İbnü'l-Hadîd, Ebû Hâmid İzzüddin el-Medâinî, Tâ'likâ ale’l-Muhassal, İstanbul Üniversitesi Yazma Eserler Kütüphanesi, AY274.

İbnü'l-Melâhimî, Rüknüddin Mahmûd el-Hârizmî, el-Fâ'ik fî usûli'd-dîn, thk. Faysal Büdeyr Han, Kahire: Dâru'l-kütüb ve'l-vesâiki'l-kavmiyye, 2010. 
, Kitâbu'l-Mu'temed fî usûli'd-dîn, thk. Martin McDermott ve Wilferd Madelung, Oxford: el-Hoda, 1991.

Kâdî Abdülcebbâr, el-Mecmû'fi'l-Muhît bi't-teklîf, thk. Jean Yusuf Houben, I, Beyrut: el-Matbaatü'l-Katûlikiyye, 1965.

-------, Şerhu'l-Usûli'l-hamse, thk. Abdülkerim Osman, Kahire: Mektebetü Vehbe, 1996.

Kahraman, Hüseyin, “Cüveynî̀de İlliyet Teorisi”, doktora tezi, Marmara Üniversitesi, 2015.

Kaş, Murat, “Seyyid Şerîf Cürcânî'de Zihnî Varlık”, doktora tezi, Marmara Üniversitesi, 2017.

Kiyâ el-Herrâsî, Usûlü'd-dîn, Dâru'l-Kütübi'l- Misriyye, Kelâm 290.

Koloğlu, Orhan Şener, "Ebû Hâşim el-Cübbâînin Ahvâl Teorisi Üzerine Bazı Mülahazalar”, Uludağ İlahiyat Fakültesi Dergisi 16/2 (2007), 195-214.

el-Muktarah, Ebü'l-İzz, Şerhu'l İş̧âd, nşr. Nezihe Ma'ric, I, Lübnan: Dâru İbn Hazm, 2014.

Platon, Timaios, çev. Erol Güney ve Lütfi Ay, İstanbul: Sosyal Yayınlar, 2001.

Porfiryus, Îsâgûcî, trc. Ebû Osmân ed-Dimaşkî, thk. Ahmed Fuâd el-Ahvânî, Kahire: Dâru İhyâi'l-kütübi'l-Arabiyye, 1952.

Porphyry, "Isagoge", Five Texts on the Medieval problem of Universals: Porphyry, Boethius, Abelard, Duns Scotus, Ockham, çev. ve ed. Paul Vincent Spade, 1-20, Indianapolis: Hackett Publishing Company, 1994.

Shihadeh, Ayman, “Classical Ash'arī Anthropology: Body, Life and Spirit”, The Muslim World 102 (2012), 433-77.

Şehristânî, Nihâyetüll-ikdâm fí ilmi'l-kelâm, thk. Ahmed Ferîd el-Mezîdî, Beyrut: Dâru'l-Kütübi'l-İlmiyye, 2004.

Thiele, Jan, “Abū Hāshim al-Jubbā'ī's (d. 321/933) Theory of 'States' (aḥwāl) and its Adaption by Ash'arite Theologians", The Oxford Handbook of Islamic Theology, ed. Sabine Schmidtke, 364-383, Oxford: Oxford University Press 2016.

Tilimsânî, Şerefeddîn el-Fihrî, Şerhu’l- Lüma ‘i’l-edille, thk. Nizâr Hammâdî, Kuveyt: Darü'z-Ziyâ, 20018.

Türker, Ömer, "Bir Tümdengelim Olarak Şâhitle Gâibe İstidlâl Yöntemi ve Cüveynînin Bu Yönteme Yönelttiği Eleştiriler”, İslâm Araştırmaları Dergisi 18 (2007), 1-26.

-------, “Eş‘arî Kelâmının Kırılma Noktası: Cüveynînnin Yöntem Eleştirileri”, İslâm Araştırmaları Dergisi 19 (2008), 1-23.

Üçer, İbrahim Halil, İbn Sînâ Felsefesinde Suret, Cevher ve Varlık, İstanbul: Klasik, 2017.

Wisnovsky, Robert, "Essence and Existence in the Eleventh- and Twelfth-Century Islamic East (Mašriq): A Sketch", The Arabic, Hebrew and Latin Reception of Avicenna's Metaphysics, ed. Dag Nikolaus Hasse ve Amos Bertolacci, 27-50, Berlin: De Gruyter, 2012.

Wolfson, Harry Austryn, The Philosophy of the Kalam, Cambridge: Harvard University Press, 1976.

Yavuz, Yusuf Şevki, “Ahvâl”, DİA, II, 190-92. 